\title{
DISSOLUTION OF ALUMINUM-CLAD THORIA
}

\author{
ClAUde B. GOOdLETt TIS TIIE \\ HARCOURT BULL, II RECORD COPI.
}

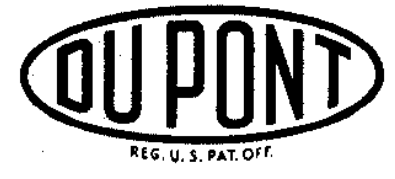

E. I. du Pont de Nemours \& Co.

Savannah River Laboratory

Aiken, S. C. 29801

PREPARED FOR THE U. S. ATOMIC ENERGY COMMISSION UNDER CONTRACT AT(07-2)-1 


\section{NOTICE}

This report was prepared as an account of work sponsored by the United States Government. Neither the United States nor the United States Atomic Energy Commission, nor any of their employees, nor any of their contractors, subcontractors, or their employees, makes any warranty, express or implied, or assumes any legal liability or responsibility for the accuracy, completeness or usefulness of any information, apparatus, product or process disclosed, or represents that its use would not infringe privately owned rights.

Printed in the United States of America

Available from

National Technical Information Service

U. S. Department of Commerce

5285 Port Royal Road

Springfield, Virginia 22151

Price: Printed Copy $\$ 4.00$; Microfiche $\$ 2.25$ 
DP-1072

UC-10

\title{
DISSOLUTION OF ALUMINUM-CLAD THORIA
}

by

\author{
Claude B. Goodlett \\ and \\ Harcourt Bul1, III
}

Approved by

A. S. Jennings, Research Manager

Separations Engineering Division

Publication Date: December 1974

\section{E. 1. du Pont de Nemours \& Co. Savannah River Laboratory \\ Aiken, S. C. 29801}

PREPARED FOR THE U. S. ATOMIC ENERGY COMMISSION UNDER CONTRACT ATI07-21-1 


\begin{abstract}
A reverse codissolution process was developed to dissolve aluminum-clad thoria. In the reverse codissolution process, thoria from a previous dissolving cycle is dissolved in strong acid, then fresh aluminum-clad slugs are added to the partially spent dissolvent and the aluminum 18 dissolved. The advantages of reverse codissolution are: 1) high inftial acid concentration enhances thoria dissolution, and 2) subsequent mercury-catalyzed dissolution of the aluminum reduces acid concentrations sufficiently to allow solvent extraction without requiring feed adjustment by steam stripping. Agitation by either submerged steam coils or air-1ift circulators increased the dissolution rates from 0.9 pound $\mathrm{ThO}_{2}$ per hour per square foot of dissolver bottom to 4.3 and $17.2 \mathrm{lb} \mathrm{ThO}_{2} /\left(\mathrm{hr}-\mathrm{ft}^{2}\right)$, respectively. Thorla that had $1 \mathrm{wt} \%$ magnesia incorporated during 1 ts preparation

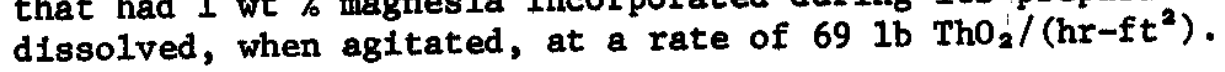




\section{CONTENTS}

\section{$\underline{\text { Page }}$}

Introduction .................. 7

Summary .................... . 8

Process Description . . . . . . . . . . . . . 8

Process Equipment. . . . . . . . . . . . . . . 11

Dissolution Tests . . . . . . . . . . . . . 18

Unagitated Dissolution Tests . . . . . . . . . 18

AgItation by Bottom Steam Co11 . . . . . . . . . 18

Pot Dissolver Tests . . . . . . . . . . . 21

Annular D1ssolver Tests . . . . . . . . . 21

Capaclty of H-Area Pot Dissolver and F-Area
Annular Dissolver . . . . . . . . . 22

Agitation by Air Lift Circulators........... . 24

Design of Alr Lift Circulator . . . . . . . . . 24

Effect of Air Flow on D1ssolution Rate . . . . . 26

Large Scale Tests in Annular Dissolver Mockup . . . 26

Dissolution of Thoria Containing Magnesia. . . . . . 29

Capacity of EM Annular Dissolver for F-Area. . . . . . 31

Entrainment of Thoria in Dissolver Solution . . . . . 34

H-Area Pot Dissolver Experience. . . . . . . . . . . 35

References ................... . . 36 


\section{LIST OF FIGURES}

Figure

Page

1 Solubility of Thorium Nitrate-Aluminum

Nitrate in Nitric Acid . . . . . . . . . 10

2 Semiworks Dissolver. . . . . . . . . 12

3 Horizontal Steam Coil and Protective Grating

for Pot Dissolver. . . . . . . . . . 13

4 Sectional Mock-Up of Annular Dissolver ..... 14

5 Air Lift Circulators in Annular Dissolver

Mock-up. ............... 15

6 Funnel Dissolver ............ 16-17

7 Typical Charge of Aluminum Canned Thoria

Fuel Elements . . . . . . . . . . 19

8 Typical Thoria Heel ........... 20

9 Typical Plant Thoria Dissolving Cycle..... . 23

10 Air Lift Circulator Design ......... 24

11 Effect of Circulator Air Flow on Thoria

Dissolution. ............ 27

12 Dissolution of Thoria Agitated by Air Lift

Circulators............. 28

13 Agitated Dissolution of Thoria Containing Magnesia............... 30

14 Air Lift Circulators in Plant Annular

Dissolver .............. 32

15 Protective Grating for Air Lift Circulators in Plant Annular Dissolver ......... 33

16 Capacity of Extra Machinery Annular Dissolver for F-Area ........... 34 


\section{LIST OF TABLES}

Table

Page

I Typical Time Cycle for H-Area Pot Dissolver . . . 23

II Large-Scale Dissolution Tests with Air Lift Circulators .............. 27

III Dissolution Characteristics of Thoria Containing Magnesium 0xide . . . . . . . . . . 29

IV Unagitated Dissolution of Thoria Containing Magnesia ................ 31

$\checkmark \quad$ Entrained Thoria in Dissolver Solution . . . . 34 
$-6-$ 


\section{DISSOLUTION OF ALUMINUM-CLAD THORIA}

\section{INTRODUCTION}

A process was developed at the Savannah River Laboratory (SRL) for separating and purifying ${ }^{239} \mathrm{U}$ in existing plant equipment. The ${ }^{233} \mathrm{U}$ was obtained by irradiating thoria in aluminum cans in the production reactors at the Savannah River Plant (SRP). Principal steps in the process include:

- Dissolution of the fuel elements.

- Sorption of ${ }^{233} \mathrm{~Pa}$ on manganese dioxide.

- Separation of ${ }^{233} \mathrm{U}$ and thorium from each other and from aluminum, protactinium, and fission products in a solvent extraction cycle. The extractant was tributylphosphate (TBP) at a concentration of $30 \mathrm{vol} \%$ in high purity kerosene.

- Purification of the ${ }^{299} \mathrm{U}$ from residual thorium, protactinium, and fission products in a second cycle of solvent extraction with $7-1 / 2$ vol \% TBP in high purity kerosene.

- Concentration of the ${ }^{239} \mathrm{U}$ by cation exchange.

- Precipitation of ${ }^{239} \mathrm{U}$ as ammonium uranate.

- Calcination of the ammonium uranate to uranium trioxide.

- Storage of the recovered thorium as a concentrated solution of thorium nitrate.

Laboratory-scale dissolution studies ${ }^{1,2}$ indicated that codissolution of the aluminum can and irradiated thoria with boiling $13 \mathrm{M}$ $\mathrm{HNO}_{3}-0.025 \mathrm{M} \mathrm{HF}-0.1 \mathrm{M} \mathrm{Al}\left(\mathrm{NO}_{3}\right)_{3}$ was the most satisfactory method for preparing the feed for solvent extraction. Significant variables affecting the dissolution rate of thoria were the degree of agitation, the particle size of the thoria, and whether the thorla had magnesia (MgO) incorporated during its preparation. Experiments were conducted to determine dissolution rates and to investigate practical methods of agitation in SRP equipment for normal production grade thoria, and for thoria incorporating $1 \% \mathrm{MgO}$. There was no attempt to study the effect of particle size of the thoria. 


\section{SUMMARY}

A reverse codissolution process was developed to dissolve residual thoria in strong nitric acid prior to the mercury-catalyzed dissolution of additional aluminum-canned thorla fuel elements. This procedure allows thorla to be dissolved at the highest acid concentration possible (thoria dissolution rate is dependent on acid concentration) and dissolves aluminum at low acid concentration (aluminum dissolution is virtually independent of acid concentration when using a mercury catalyst). This dissolving procedure produces a solution that does not require steam stripping of acid before ${ }^{233} \mathrm{~Pa}$ removal on manganese dioxide $\left(\mathrm{MnO}_{2}\right)$ cake and subsequent ${ }^{23} \mathrm{U}$ recovery by solvent extraction.

The moderate agitation produced by boiling action at the surface of a horizontal steam coll burled in a bed of thorla powder increased the dissolution rate by a factor of about 5 . The dissolution rate increased from 0.9 pounds of thorfa per square foot of dissolver bottom to $4.3 \mathrm{lb} \mathrm{ThO}_{2} /\left(\mathrm{hr}-\mathrm{ft}^{2}\right)$ when a steam coll was installed on the floor of the dissolver.

The thoria dissolution rate was increased by installation of two partially buried, air-lift circulators per square foot of dissolver bottom area. At circulator air flows of $3 \mathrm{scfm}$ each, the thorla dissolved at a rate of $17.2 \mathrm{Ib} \mathrm{ThO}_{2} /\left(\mathrm{hr}-\mathrm{ft}^{2}\right)$.

The incorporation of 1 wt \% Mgo during the preparation of thorla (calcined at $2100^{\circ} \mathrm{F}$ for 4 hours) increased the dissolution rate four-fold to $68.8 \mathrm{lb} \mathrm{ThO}_{2} /\left(\mathrm{hr}-\mathrm{ft}^{2}\right)$ using the alr lift circulators at an air flow of $3 \mathrm{scfm}$. Mgo incorporation did not increase the dissolution rate if the thoria was not agitated.

A portion ( 0.3 to $0.5 \%$ ) of the thoria was entrained when the end of a suction pipe was located 3 to 9 inches above the settled thoria. Filtration was unsatisfactory because the entrained thoria plugged the filter; however, centrifuging decreased the entrained thoria to only $0.006 \%$ of the total thorfum.

\section{PROCESS DESCRIPTION}

Laboratory studies ${ }^{1,2}$ showed codissolution of aluminum cans and thoria to be superior to separate removal of the can by acidic or alkaline decladding. The recommended codissolvent is $13 \mathrm{M}$ $\mathrm{HNO}_{3}$ containing $0.025 \mathrm{M} \mathrm{HF}$ and $0.1 \mathrm{M} \mathrm{Al}\left(\mathrm{NO}_{3}\right)_{9}$. The fluoride ion catalyzes thoria dissolution and is complexed by the aluminum to reduce corrosion of the dissolver vessel. When irradiated thoria was boiled for 24 hours in an acidic decanning solution $\left[6 \mathrm{M}\right.$ HNO $\left.-10^{-3} \mathrm{M} \mathrm{Hg}\left(\mathrm{NO}_{3}\right)_{2}\right]$, about $20 \%$ of the ${ }^{293} \mathrm{U}$ was leached from the thoria, indicating acid decanning is probably unsuitable 
when the decanning solution is to be discarded. The alkaline decanning solution (4.3M NaOH-3M NaNO 3 ) was fairly viscous, and fine thoria particles were entrained when the spent solution was removed. Exposure to the alkaline solution retarded subsequent dissolution of thoria. Neither the acid decanning solution nor the alkaline decanning solution dissolved thoria appreciably.

Normal codissolution, 1.e., adding the dissolvent to a charge of aluminum-jacketed slugs, results in an unacceptably long time cycle. This is due to the rapid dissolution of the aluminum cladding which consumes about one half of the nitric acid. The thoria dissolution rate is a strong function of actd concentration and is therefore relatively slow compared to the rate obtained with fresh dissolvent. Solvent extraction requirements prohibit the use of a larger excess of acid, and higher fluoride concentrations cause the precipitation of $\mathrm{ThF}_{4}$.

A more efficient process is that of "reverse codissolution," which separates the initial thorla reaction from the dissolution of the aluminum cans. This process consists of: 1) dissolution of the thoria "heel" from a previous cycle in the standard boiling dissofvent, 2) cooling of the partially spent dissolvent $\left(8 \mathrm{M} \mathrm{H}\right.$ and $\left.1 \mathrm{M} \mathrm{Th}^{4}\right)$, 3) charging of aluminum-canned thoria slugs, 4) addition of mercury catalyst, and 5) dissolution of the aluminum cans to a final product concentration of 1.0M $\mathrm{Th}^{4}, 2.0 \mathrm{M} \mathrm{Al}^{\mathrm{s}^{+}}$, and $2 \mathrm{M} \mathrm{HNO}_{3}$. The thoria released from the dissolved cans remains as a "heel" for the subsequent dissolution cycle. The advantages of "reverse codissolution" are: 1) acid-dependent thoria dissolution proceeds at the highest possible rate at the high acid concentrations, and 2) subsequent mercury-catalyzed dissolution of the aluminum reduces acid concentrations sufficiently to allow solvent extraction without the need of feed adjustment by steam stripping. The concentration of the final dissolver product (IM $\mathrm{Th}^{4}, 2 \mathrm{M} \mathrm{AI}^{{ }^{+}}{ }^{+}$, and $2 \mathrm{M} \mathrm{HNO}_{3}$ ) is high, and water is added prior to cooling to produce a soluble, more dilute solution at ambient temperatures (Figure 1). 


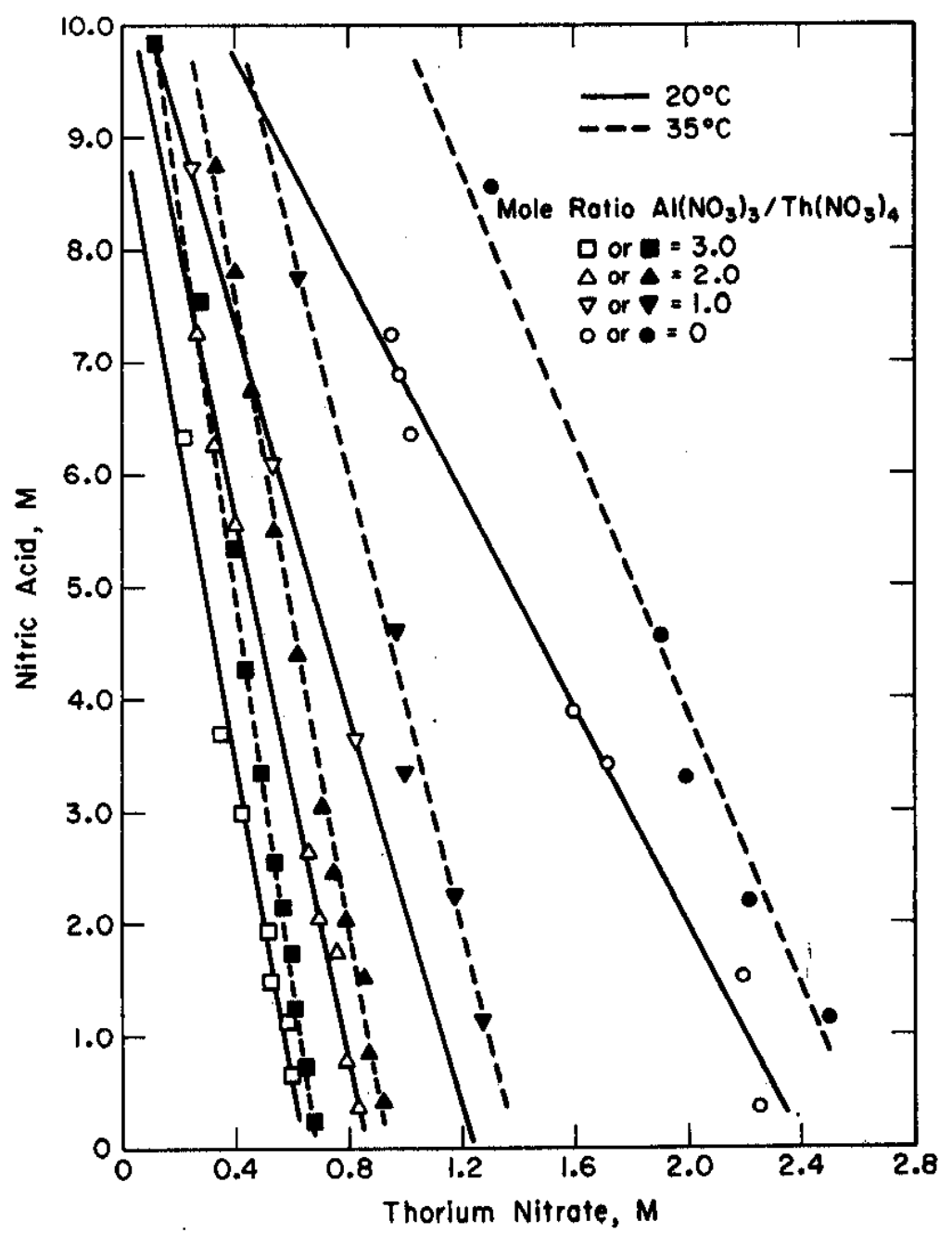

Figure 1. Solubility of Thorium Nitrate-Aluminum Nitrate in Nitric Acid 


\section{PROCESS EQUIPMENT}

Either of two types of dissolvers would be used, depending on which separations plant the thoria would be processed in. In the H-Area separations plant, a normal pot dissolver would be used. An annular dissolver, which contains a high density concrete center to provide nuclear criticality protection, would be used in the F-Area separations plant.

The 11-ft-4-in, diameter H-Area pot dissolver was simulated in the SRL process studies area (TNX) with a 6-ft-diameter by 7-ft-high tank equipped with wall-mounted steam colls and a 4-ft-diameter fuel crib (Figure 2). A horizontal steam coll and protective grating (Figure 3 ) were added to the bottom of the tank during the tests. The steam coll was made of 1-in. Schedule 40 pipe on 3-in. centers. The cross-sectional area of the coil covered $44 \%$ of a $4-\mathrm{ft}$-diameter c1rcle ( $19 \%$ of the total area of the tank bottom).

The F-Area annular dissolver ( $5 \mathrm{ft}-7-\mathrm{in} . \mathrm{x} 10 \mathrm{ft}-2-\mathrm{in}$. diameter annulus) was simulated with a sectional mockup. The mockup (Figure 4) was vertically similar to the plant dissolver and was rectangular (1-ft by $2-\mathrm{ft}$ ) at the bottom (cross-sectional area was $1 / 27$ of the plant dissolver). The dissolver had vertical steam coils and a fence dividing the annular space into two sections: a fuel crib (inner) and a heating/cooling section (outer). A horizontal steam coil made of $1-1 / 2-i n$. Schedule 40 pipe on $2.4-i n$. centers (the cross-sectional area of the coil covered $79 \%$ of the bottom area) was installed on the bottom of the dissolver.

During subsequent dissolution tests with this sectional mockup, the bottom steam coils were replaced by four alr lift circulators (Figure 5). The individual circulators were made of 10-inch lengths of $2-1 \mathrm{n}$. Schedule 40 pipe and were positioned vertically $1-1 / 2-1 \mathrm{n}$. above the dissolver bottom and evenly spaced in each of the $1-f t$ square "annular" sections. Four 1/4-in.-wide by 1-1/2-in.-long slots were cut into the bottom of each circulator to improve entry of the thoriadissolvent mixture. Air was introduced through the open end of a 1/2-in. Schedule 40 pipe located below the bottom edge of each circulator. A manifold in each dissolver annulus supplied air through a restricting orifice to individual circulators. A grating was placed over the circulators in the fuel crib to protect them from damage during charging of fuel slugs.

The dissolution rate of thoria as a function of air flow rate was determined with a small funnel-shaped dissolver (Figure 6) having a 0.5- $\mathrm{ft}^{2}$ bottom area and a single air lift circulator (described above). This small dissolver allowed a greater number of tests with the limited quantity of thoria available. The funnel shape of the dissolver returned all of the undissolved thorla par- 
ticles to the 10-in.-diameter dissolving section. The dissolvent was heated by an annular steam chest located near the air lift circulator.

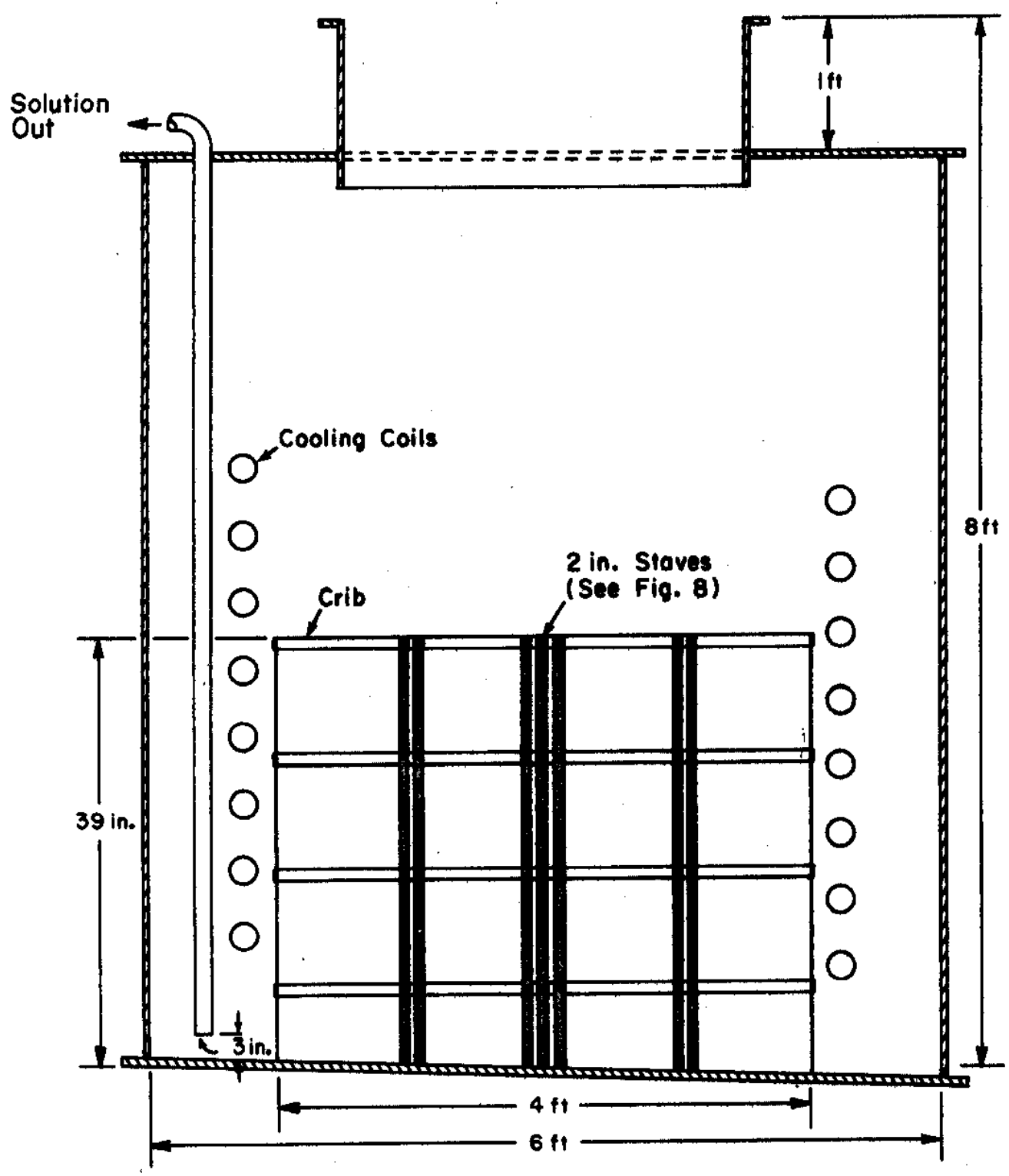

Figure 2. Semiworks Dissolver 

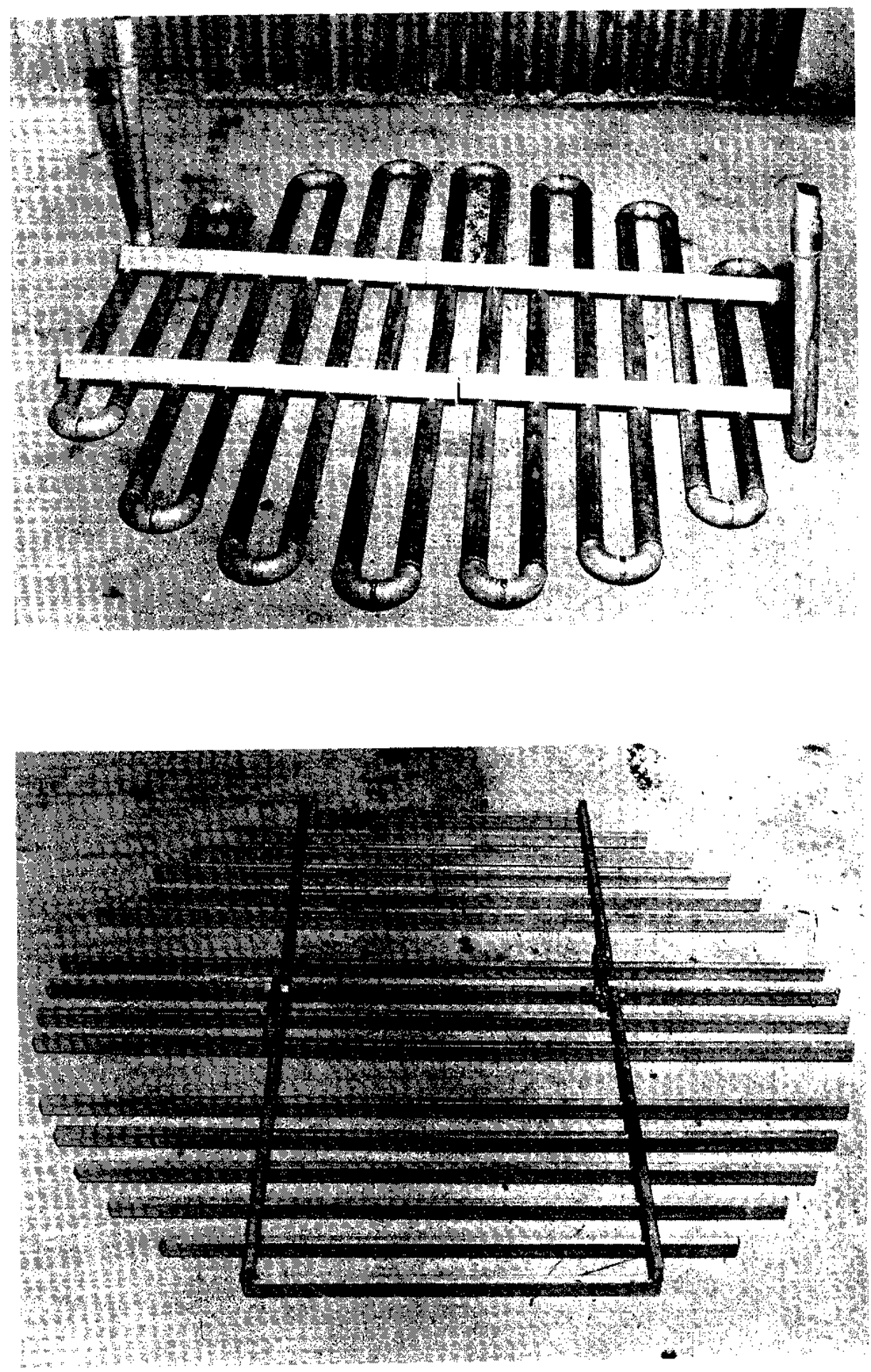

Figure 3. Horizontal Steam Coil and Protective Grating for Pot Dissolver 


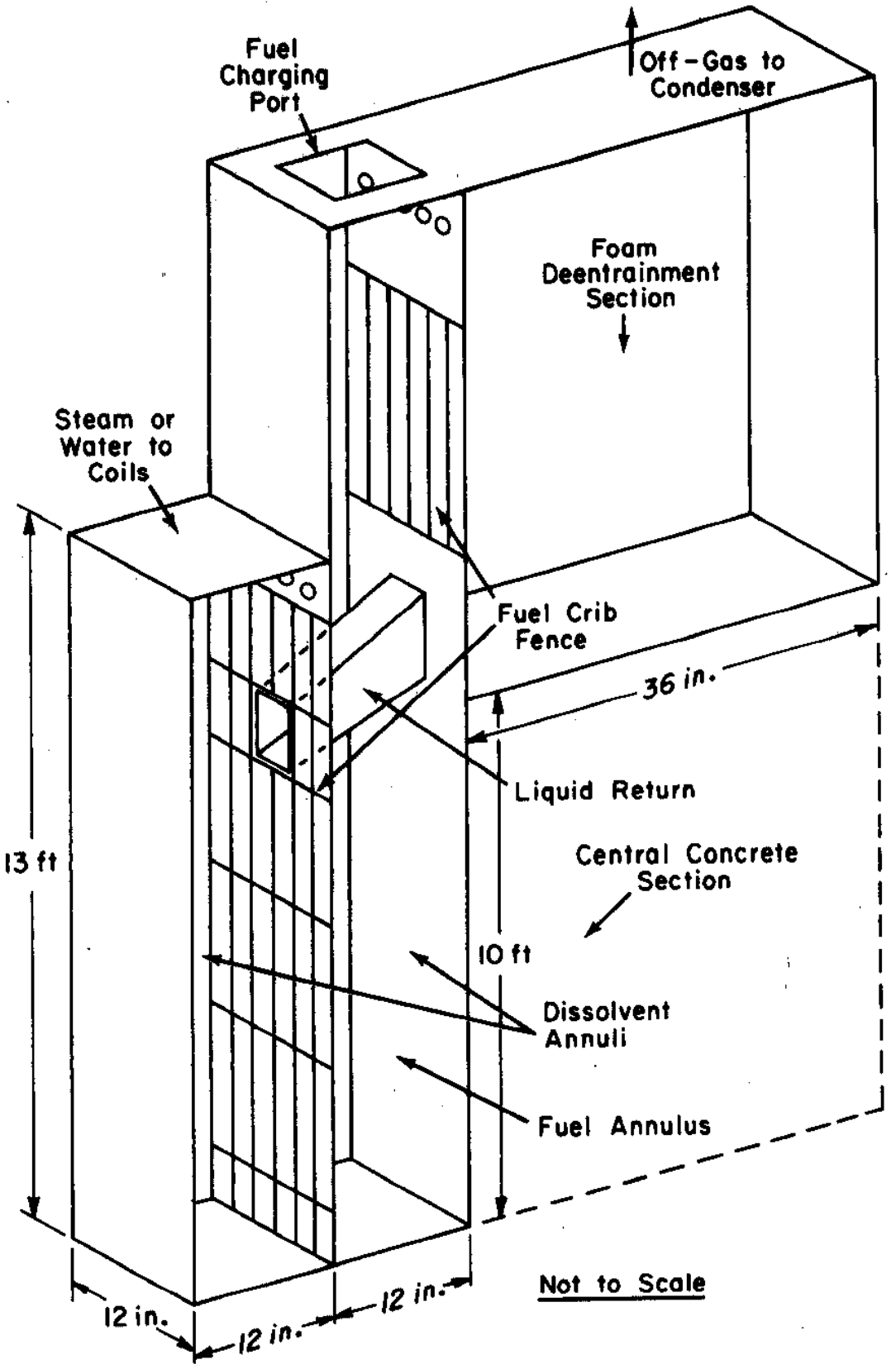

Figure 4. Sectional Mock-Up of Annular Dissolver 


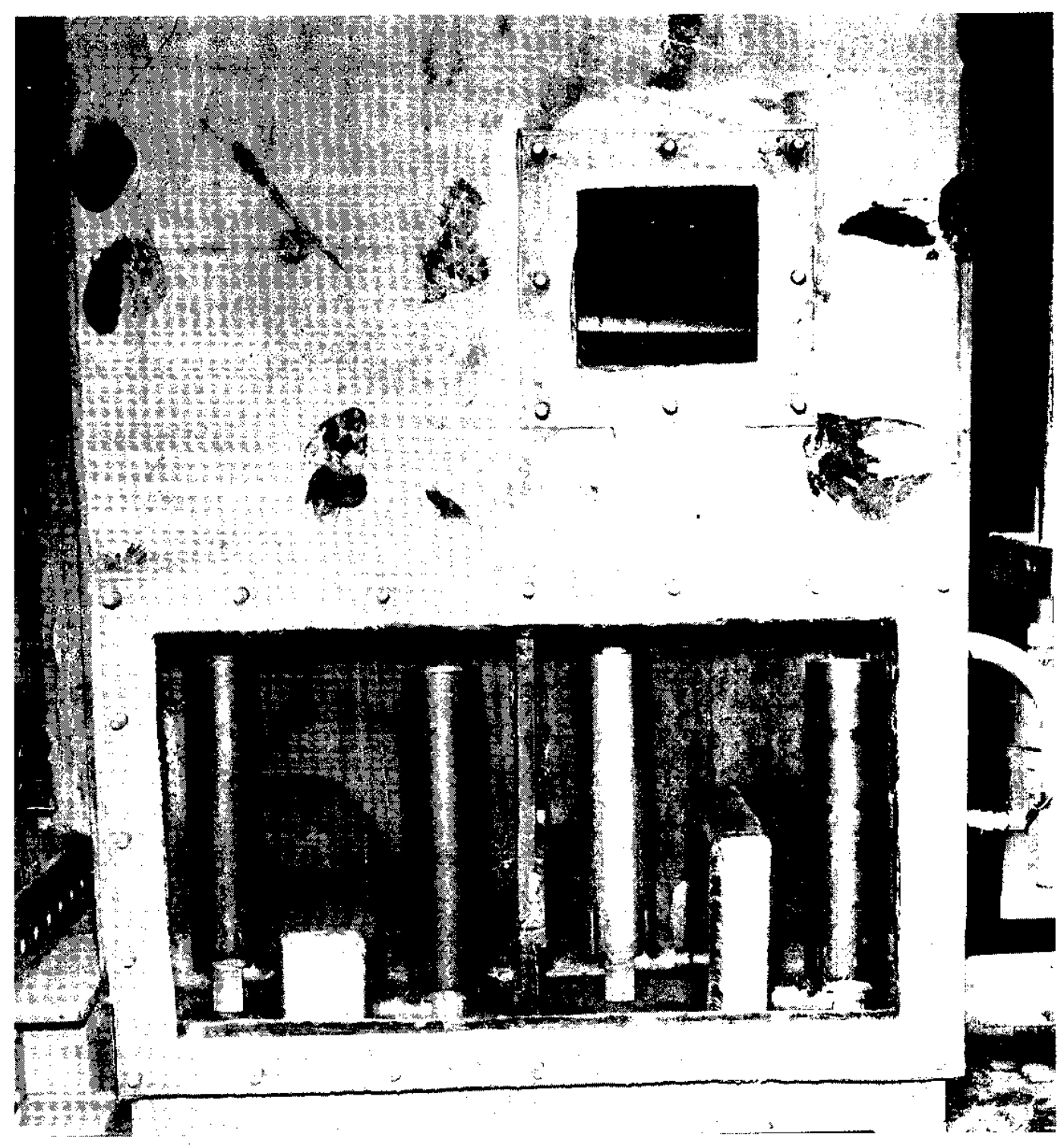

Figure 5. Air Lift Circulators in Annular Dissolver Mock-Up 


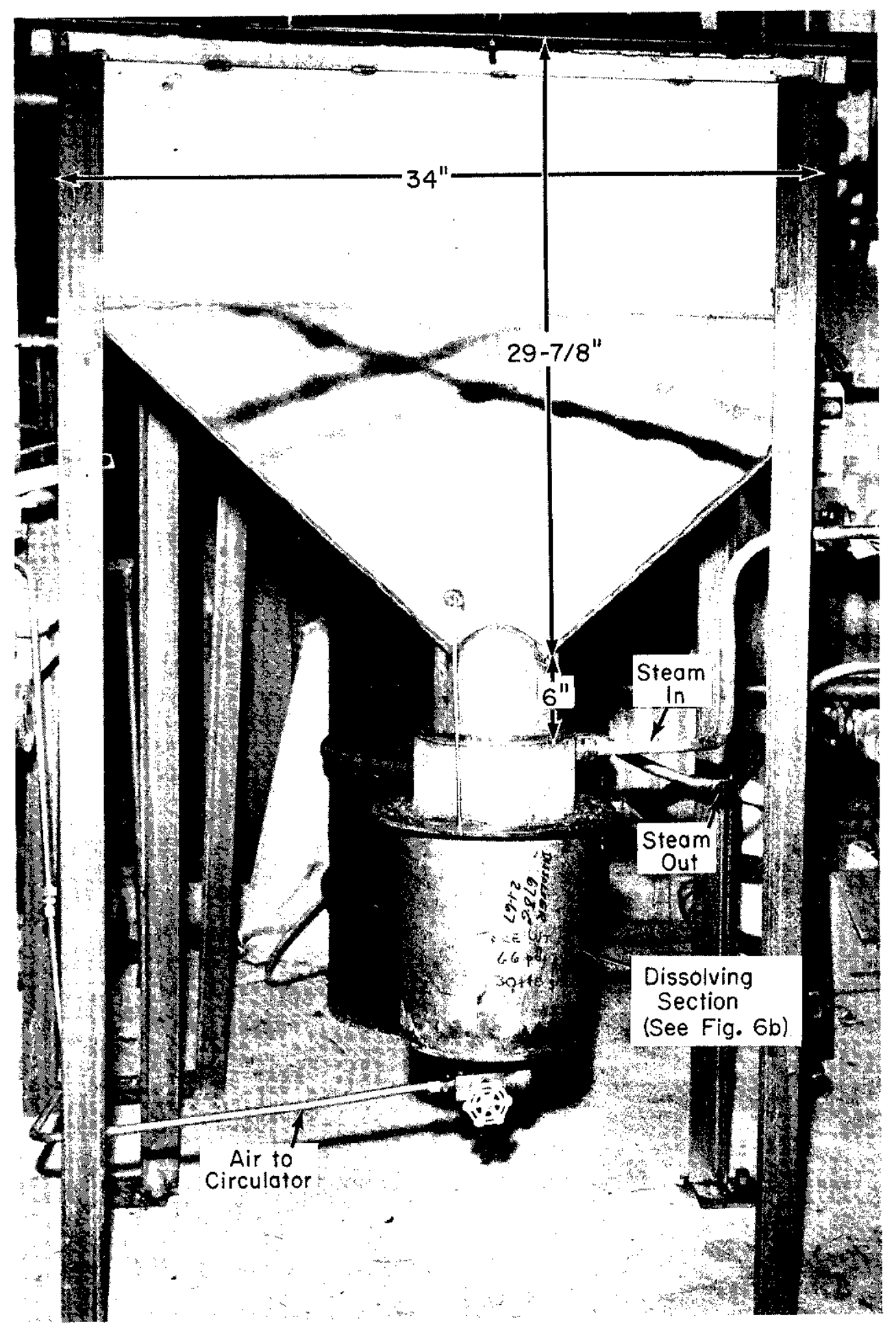

a. Installed Unit

Figure 6. Funnel Dissolver 


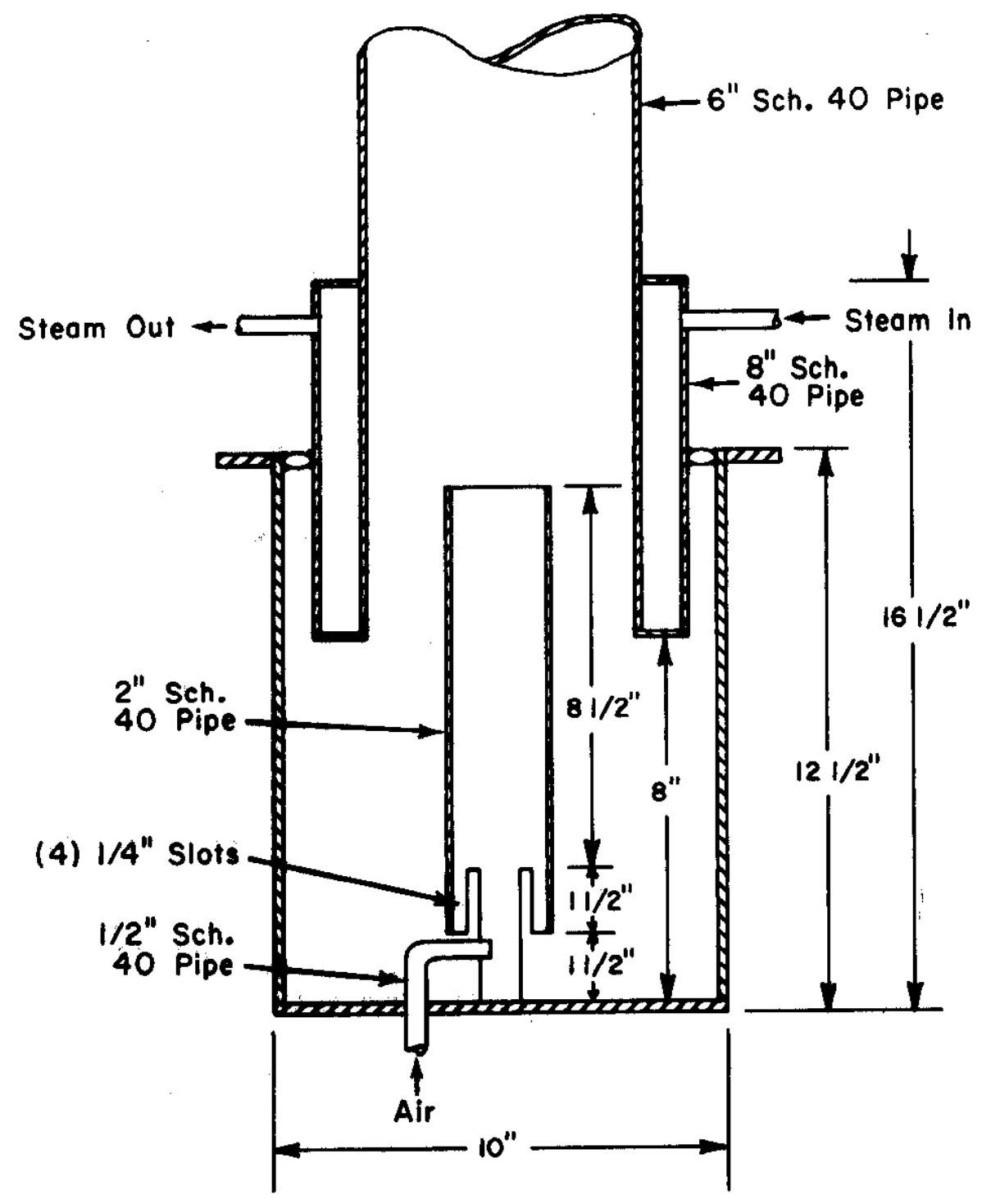

b. Dissolving Section

Figure 6. Funnel Dissolver (cont'd) 


\section{DISSOLUTION TESTS}

\section{Unagitated Dissolution Tests}

Inttial large-scale dissolution tests were made in the 6-ft.diameter pot dissolver (Figure 2 ), which was equipped with only wallmounted steam colls. A thorla "heel" weighing 805 pounds was left in the dissolver by chemically ( $\mathrm{NaOH}-\mathrm{NaNO}_{3}$ ) removing the aluminum cans from a typical charge of fuel elements (Figure 7). As the aluminum cans dissolved, the dense thorla powder settled quite uniformly in a compact layer on the bottom of the dissolver (Figure 8). Additional fuel elements containing 813 pounds of thorla were charged on top of the thoria "heel," and a partial codissolution was made with 370 gallons of bolling $12.5 \mathrm{M}$ HNO,$-0.025 \mathrm{M} \mathrm{HF}-0.1 \mathrm{M} \mathrm{AI}\left(\mathrm{NO}_{3}\right)_{3}$ (hereafter referred to as standard dissolvent). Dissolution proceeded very slowly because the active dissolution zone was restricted to the top surface of the densely packed thorla. The calculated rate of "penetration" of the dissolvent into the thorla layer was 0.44 millimeters per hour. Three laboratory tests in $3-$ and 4-in.-dlameter vessels verified this penetration rate with values ranging between 0.37 and $0.49 \mathrm{~mm} / \mathrm{hr}$. When a concentration of $0.5 \mathrm{M} \mathrm{Th}^{4+}, 0.9 \mathrm{M} \mathrm{Al}^{3+}$, and $8.4 \mathrm{M} \mathrm{HNO}_{3}$ was reached, the average dissolution rate was $0.9 \mathrm{lb} \mathrm{ThO}_{2} /\left(\mathrm{hr}-\mathrm{ft}^{2}\right)$, which is equivalent to a processing capacity of 0.9 ton $\mathrm{ThO}_{2} /$ day in the larger (11-ft 4-in.diameter) H-Area pot dissolver.

\section{Agitation by Bottom Steam Coil}

To Increase the thoria dissolution rate, studies were made to develop a practical means of increasing the area of contact between the dissolvent and the densely packed thorla layer? One of the proposed methods applicable to plant equipment utilized the turbulence generated by bolling at the surface of a horizontal steam coll burled in the thoria layer. Tests in glassware with a small steam coll showed that a thorla depth of about 2-1/2-in, above the top of the coil was the maximum that could be present and still allow suspension of thoria particles by boiling. Large-scale tests showed that thorla dissolution stopped when the thoria level dropped below the top of the steam coll (see Annular Dissolver Tests below). The portion of the tank bottom covered by steam coils should be as large as possible as agitation by bollup only affects the thoria directly above the coils. 


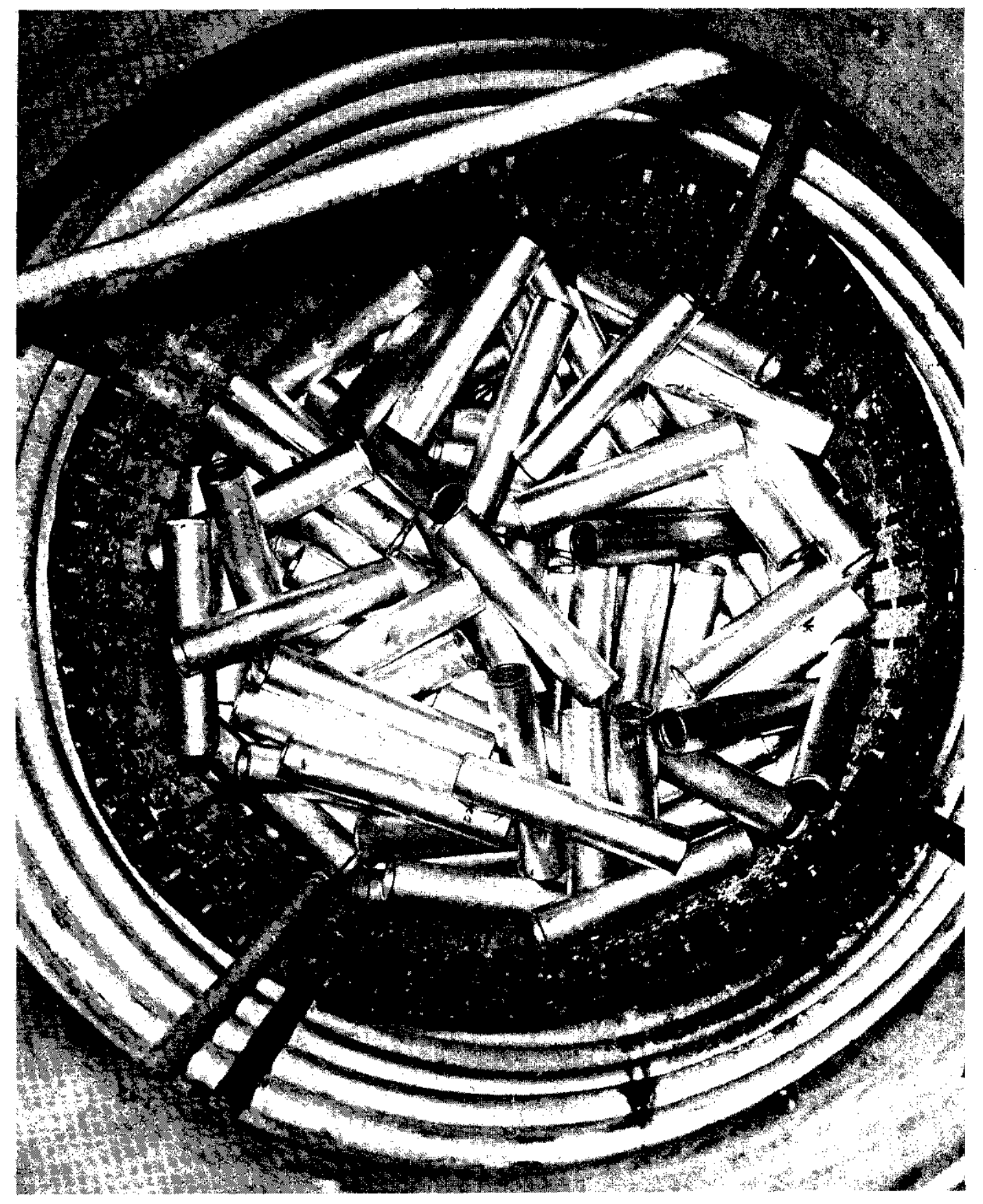

Figure 7. Typical Charge of Aluminum Canned Thoria Fuel Elements 


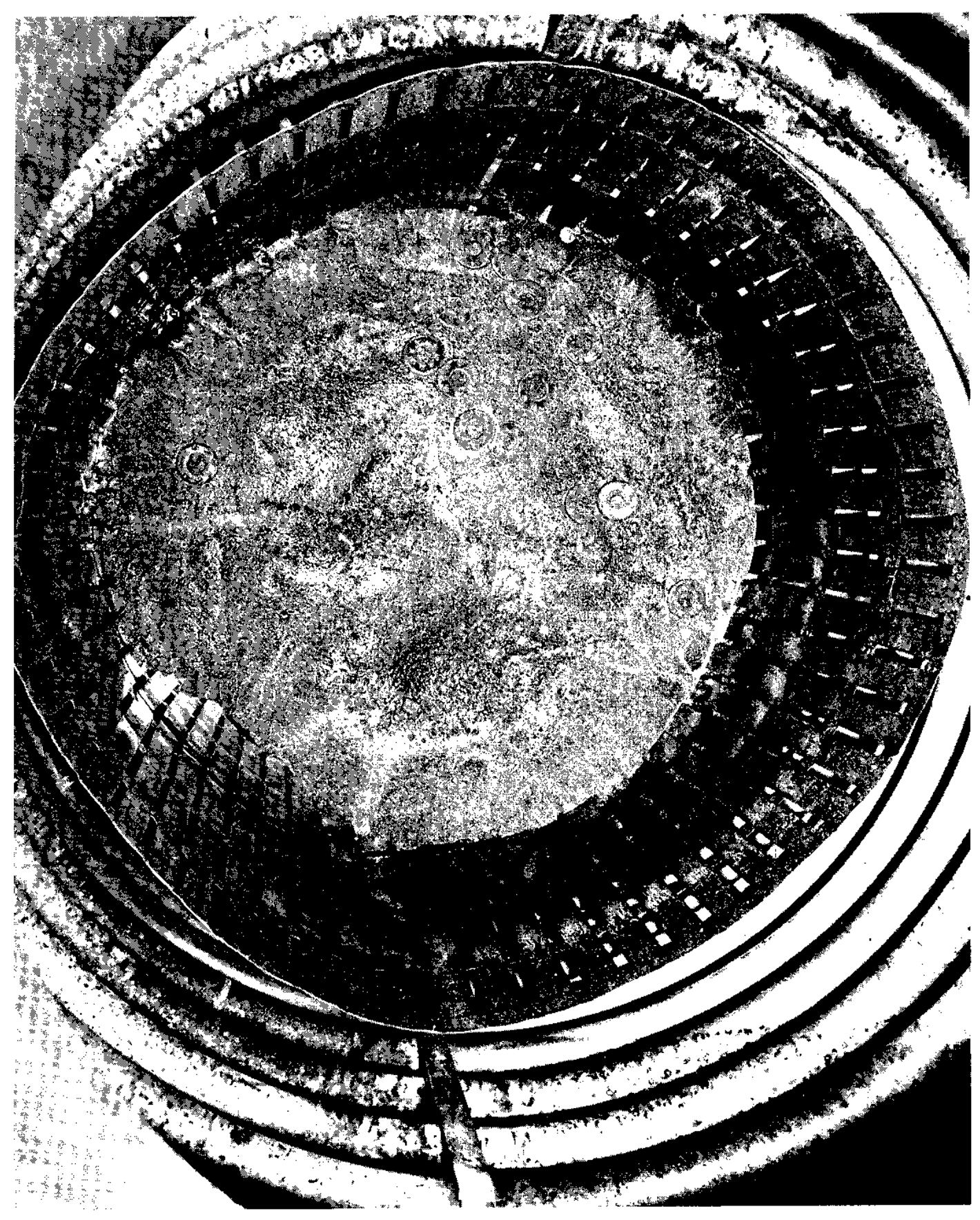

Figure 8. Typical Thoria Heel 


\section{Pot Dissolver Tests}

The pot dissolver was modifled to include a horizontal steam coil which covered 20 percent of the total bottom area. Two tests were made in which aluminum cans containing 850 pounds of thoria were partially codissolved with a 720-pound thorla "heel" in 800 gallons of standard dissolvent. At a product concentration of $0.05 \mathrm{M} \mathrm{Th}^{4+}$, $0.8 \mathrm{M} \mathrm{Al}^{3+}$, and $8.4 \mathrm{M} \mathrm{H}^{+}$, the dissolution rate was $1.91 \mathrm{~b} \mathrm{ThO}_{2} /\left(\mathrm{hr} \mathrm{ft}^{2}\right)$ a two fold increase over the unagitated tests. The aluminum cans were not dissolved completely in either test.

Because solvent extraction feed must be adjusted to $0.5 \mathrm{M} \mathrm{Th}^{4}$, 1. $0 \mathrm{M} \mathrm{Al}^{\mathrm{s+}}$, and 0.1 to $1.0 \mathrm{M} \mathrm{H} \mathrm{H}^{+}$, further dissolution tests were made to determine whether the product acid concentration (8.5M) could be further reduced without additional processing steps such as removal of nitric acid by steam stripping. Two steam-coil-agitated dissolution tests were made in the pot dissolver. In the first test, aluminum-canned thorla fuel elements (860 pounds of thoria) were added to a 1000-pound thoria "heel" and partially codissolved in 400 gallons of standard dissolvent to which $\mathrm{Hg}^{2}$ had been added as a catalyst to increase the dissolution of aluminum. The dissolution of thoria virtually ceased as the nitric acid decreased to about 3.0 molar and resulted in concentrations of $0.73 \mathrm{M} \mathrm{Th}^{4}$ and 2.0 $\mathrm{M} \mathrm{Al}^{3+}$. All the aluminum dissolved. The average thoria dissolution rate was $1.4 \mathrm{lb} \mathrm{ThO}_{2} /\left(\mathrm{hr}-\mathrm{ft}^{2}\right)$.

In the second test, a steam-coil-agitated, reverse codissolution test was made in the pot dissolver where 800 pounds of a thoria "heel" was partially dissolved in 400 gallons of bolling standard dissolvent to a concentration $0.9 \mathrm{M} \mathrm{\textrm {Th } ^ { 4 }}$ and $9.3 \mathrm{M} \mathrm{H}^{+}$. Empty aluminum cans welghing 160 pounds were then charged and dissolved after mercury weighing 160 pounds winal concentration of $0.9 \mathrm{M} \mathrm{Th}^{4+}, 1.7 \mathrm{M} \mathrm{Al}{ }^{3+}$ ion addition to yield a final concentration of $0.9 \mathrm{M} \mathrm{Th}^{4}, 1.7 \mathrm{M} \mathrm{Al} \mathrm{Al}^{2}$, with minor thorla dissolution occurring during the aluminum decanning step.

\section{Annular Dissolver Tests}

Because the F-Area separations plant has a solvent extraction capacity of 6 tons of thorium per day as compared with 1 ton of thorium per day in H-Area, it was anticipated that large campaigns (150 tons of thorium) would be done in F-Area. Increased dissolution capacity of the annular dissolver in F-Area, which only has one-half the bottom area of a pot dissolver, was demonstrated in the previously described rectangular mockup by installing a horizontal steam coil which covered $79 \%$ of the total bottom area. In four dissolution tests, the deptn of thorla above the steam coils was allowed to decrease to evaluate its effect during the first half of the reverse codissolution cycle; $i . e .$, thoria powder was dissolved in bolling dissolvent without subsequent charging of the aluminum-canned thoria slugs. 
In the first test, 714 pounds of thoria was partially dissolved in 165 gallons of standard dissolvent to a product concentration of $0.8 \mathrm{M} \mathrm{Th}^{4+}$ and $6.4 \mathrm{M} \mathrm{HNO}_{3}$. The average dissolution rate was $4.3 \mathrm{lb}$ $\mathrm{ThO}_{2} /\left(\mathrm{hr}-\mathrm{ft}^{2}\right)$, and the calculated thoria depth (basis: $6.5 \mathrm{~g} / \mathrm{cm}^{3}$ bulk density) was reduced from 9.8 to $5.4 \mathrm{in}$. above the top of the steam coll. In the second test, the heel from the previous test was further dissolved in 163 gallons of fresh dissolvent. During the first 33 hours, the average dissolving rate was $4.2 \mathrm{lb} \mathrm{ThO}_{2} /$ $\left(\mathrm{hr}-\mathrm{ft} \mathrm{t}^{2}\right)$, after which it decreased markedly to that obtained in the unagitated studies.

The decrease in the dissolution rate experienced in the second test apparently occurred when the depth of thoria dropped below the top of the bottom steam coil. The boiling produced at the top surface of the steam coil could not agitate the thoria heel below it, and the average dissolution rate fell to $0.8 \mathrm{lb} \mathrm{ThO}_{2} /\left(\mathrm{hr}-\mathrm{ft}^{2}\right)$. Measurement of the condensate from the bottom steam coil provided a basis for this explanation. During the first 19 hours when the steam coil was well covered and insulated from the bulk solution by the thoria layer, the average condensate rate was $0.21 \mathrm{~b} / \mathrm{min}$ and the moderate agitation produced an average dissolution rate of $3.6 \mathrm{Ib} \mathrm{ThO}_{2} /\left(\mathrm{hr}-\mathrm{ft}^{2}\right)$. During the period between 19 and 33 hours, more vigorous agitation produced an average dissolution rate of 4.9 $1 \mathrm{~b} \mathrm{ThO}_{2} /\left(\mathrm{hr}-\mathrm{ft}^{2}\right)$, and the condensate rate increased steadily to approximately $1.0 \mathrm{lb} / \mathrm{min}$ as the thoria provided progressively less insulation between the steam coil and the bulk solution. After the steam coil was completely exposed and came into direct contact with the bulk solution, the condensate rate increased slowly to $1.3 \mathrm{lb} / \mathrm{min}$ during the last 15 hours of dissolution.

The last two dissolution tests were designed to provide maximum agitation by reducing the thorla depth to the top of the bottom steam coil at a product concentration of $1 \mathrm{M} \mathrm{Th}^{4}{ }^{+}$. In both tests, 215 pounds of thoria, which is a calculated depth of $2.5 \mathrm{in}$. above the steam coils, was partially dissolved in 81 gallons of standard dissolvent giving an average dissolution rate of $5.8 \mathrm{lb} \mathrm{ThO}_{2} /\left(\mathrm{hr}-\mathrm{ft}^{2}\right)$. Separate laboratory tests made in a 4-in.-dia. glass cylinder indicated thorla is thoroughly agitated by a steam coll when covered to a depth up to $2-3 / 4 \mathrm{In}$.

\section{Capacity of H-Area Pot Dissolver and F-Area Annular Dissolver}

Based on the time cycle summarized in Table I and shown schematically in Figure 9, a processing capacity of 1.6 tons $\mathrm{ThO}_{2}$ /day should be attainable in the H-Area pot dissolver equipped with similar steam coils using the reverse codissolution scheme.

The predicted capacity of the F-Area annular dissolver equipped with simflar steam colls is 1.7 tons $\mathrm{ThO}_{3}$ /day assuming an average thoria dissolution rate of $4.3 \mathrm{lb} /\left(\mathrm{hr}-\mathrm{ft}^{2}\right)$, and using the same time $(23.5 \mathrm{hr}$ ) for other processing steps as 1isted in Table I. 
Table I. Typical Time Cycle for H-Area Pot Dissolver

Operation

Chemical addition

Heat to boiling point

Dissolve thorla heel [( 3.3 tons at $2.51 \mathrm{~b}$

Cool $\left.\mathrm{ThO}_{2} /\left(\mathrm{hr}-\mathrm{ft}^{2}\right)\right]$

Charge target elements

Heat to bolling point

Dissolve aluminum cans

Dilute, cool, and transfer

Total
Time, hours

1.5

1.0

26.1

1.0

7.0

1.0

10.0

2.0

49.6

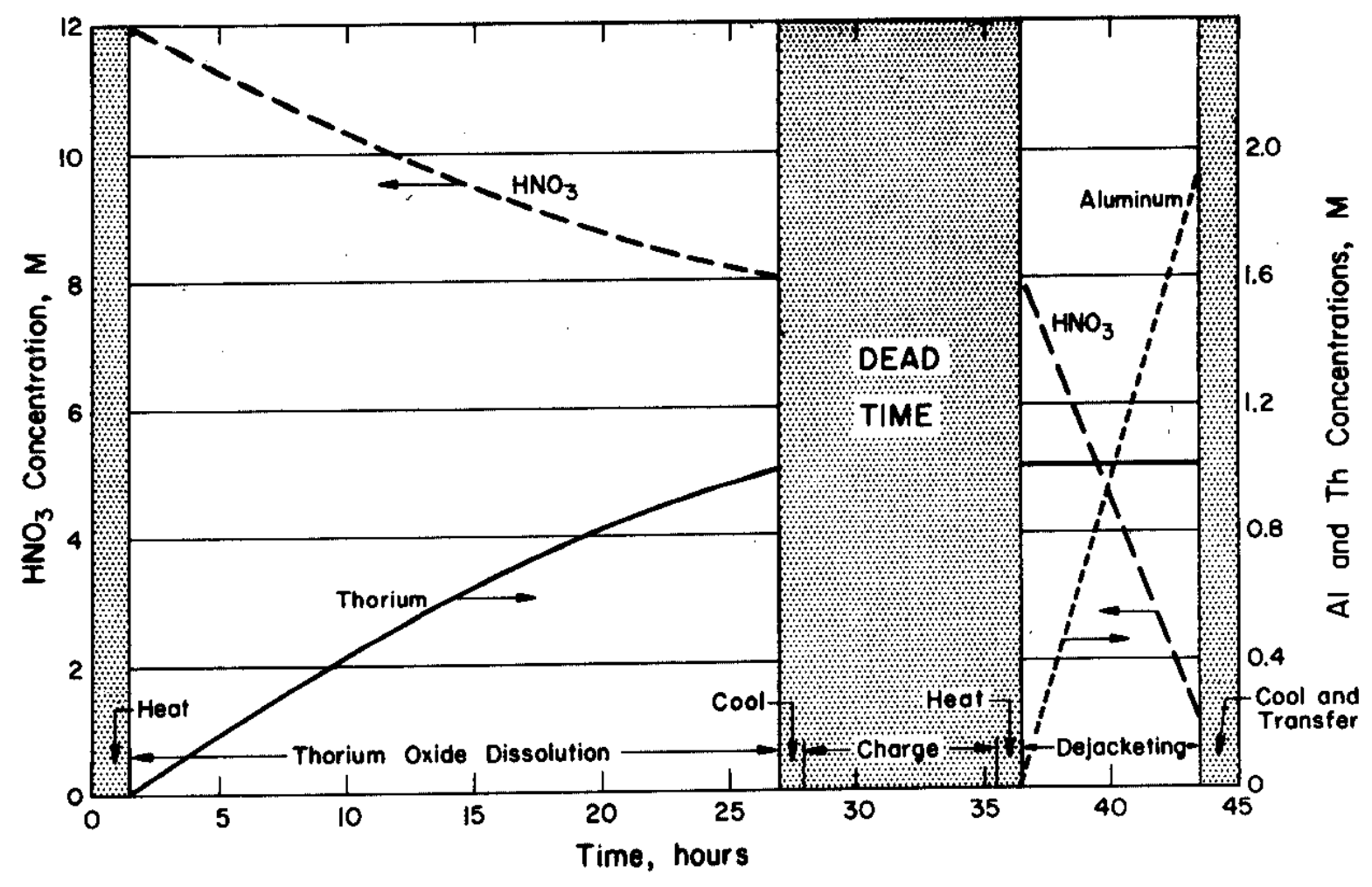

Figure 9. Typical Plant Thoria Dissolving Cycle 


\section{Agitation By Air Lift Circulators}

Based on datas obtalned from Pacific Northwest Laboratorles (PNL), studies of the effectiveness of short air lift circulators for agitating the densely packed thorla layer were initlated to increase the capactity of the F-Area annular dissolver.

\section{Design of Air Lift Circulator}

The design of the Individual circulators (Figure 10) was based on hydraulic tests using a transparent tank filled with thorla powder and water. Atr lifts, made of short lengths of 2-in.- or 3-in.-diameter pipe, fluidized particles at the surface of the thoria layer. These particles were ejected from the top of the circulator with air flow rates as low as $2 \mathrm{scfm}$. However, the fluidization range below the bottom of the circulator was less than $1 / 4 \mathrm{in}$. at air flow rates as high as $5 \mathrm{scfm}$. When the bottom of the circulator was partially buried, only the thorla fllling the inside of the circulator was "showered" out onto the surrounding surface.

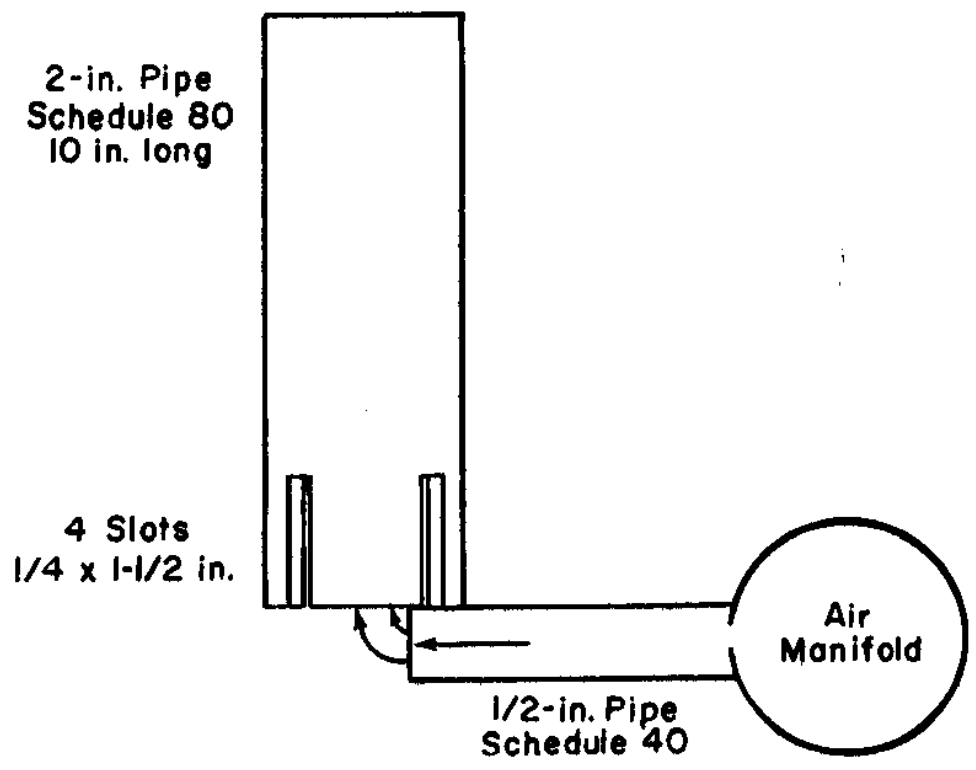

Figure 10. Air Lift Circulator Design 
Vertical slots ( $1 / 4$ in. wide) cut into the bottom of buried circulators allowed the thoria particles adjacent to the slots to become fluidized, resulting in a "caving-in" action. This action continued until a conical depression with a $110^{\circ}$ apex angle wás formed in the thoria layer surrounding the circulator. The bottom of this inverted cone colncided with the bottom of the circulator for slot-lengths up to $1-1 / 2$ in. The thoria particles falling back into this conical area continued to recirculate until they settled on the surface outside the inverted cone. The diameter of the cone was $15 \mathrm{in.}$ at a thoria depth of $5 \mathrm{in.}$

Two air lift circulators per square foot of dissolver bottom area enabled a large percentage of thoria surface to be affected even when the thorla depth, and thus cone diameter, was significantly reduced by dissolution. Because over a hundred air lift circulators would be required in the bottom of the annular dissolver, a large off-gas volume would be generated. The of $f$-gas volume could be minimized by using 2-in.-dia. air lift circulators, which require about one-half of the amount of air to produce the same internal transport velocity as 3-in.-dia. air lift circulators.

Because of potential abrasive effects of fluldized thoria on the dissolver bottom, the size and discharge direction of the hole in the air supply line to each of the air lifts were evaluated. PNL ${ }^{3}$ reported abrasion rates of $0.1 \mathrm{mils} / \mathrm{hr}$ on a stainless steel plate when air was discharged at a velocity of $220 \mathrm{ft} / \mathrm{sec}$ into a mixture of 30-mesh sand and water from a $1 / 4-1 \mathrm{n}$. -dia hole $1-1 / 2 \mathrm{in}$. away from the plate; they recommended that the discharge velocity be limited to $50 \mathrm{ft} / \mathrm{sec}$.

An upward-pointing discharge hole in the air supply line eliminates abrasive effects to the dissolver bottom, but could present a serious thorla pluggage potential. 2-in.- and 3-in.-dia air lift circulators, which had downward-pointed air discharge holes' with diameters of $1 / 2 \mathrm{in}$. and $3 / 4 \mathrm{in}$., respectively, produced no thoria movement when the discharge hole was located $1 / 2 \mathrm{in}$. above the bottom at flow rates up to 6 scfm (velocities of 74 and $33 \mathrm{ft} / \mathrm{sec}$, respectively). During these tests, the lifting efficiency was reduced because large volumes of air escaped around the outside of the circulator body even at moderate air flow rates. Apparently the restriction to flow presented by the air supply pipe (which traverses the bottom of the circulator) combined with the slotted sides was responsible for the loss of air. The horizontal discharge of air through the end of a 1/2-In.-dia air supply pipe which enters under the bottom edge of the circulator and terminates one-third of the way across the inside of the circulator was a satisfactory compromise between pluggage of an upward-pointing hole and loss of air (plus potential abrasion) from a downward-pointing hole.

The circulators were supplied with air from manifolds containing restricting orifices to avold reduced air flows to individual 
circulators that may be partially filled with thoria.

Chemical tests producing high dissolution rates at significant thoria depths suggest that the area of liquid-solid contact is increased by recirculation of fresh dissolvent down through the densely packed thoria layer; physical agitation of thorla particles is not a prerequisite for high dissolution rates. Hydraulic tests with a deeply buried (up to 10 in.) circulator produced very little "showering" of thorla particles. At shallow thorla depths, the acid recirculation continues to contribute significantly to dissolution along with the previously described thoria-showering mechanism.

The air lift circulators for the annular dissolver were installed 1-1/2 in. above the dissolver bottom and made 10-in. tall so that the tops would protrude above the settled thorla layer.

\section{Effect of Air Flow on Dissolution Rate}

A series of small-scale tests were made in the funnel-shaped dissolver to determine the dissolution rate of thorla as a function of the air flow rate. This dissolver had a bottom area of $0.5 \mathrm{ft}^{2}$ and was equipped with a single air lift circulator. In each of nine tests, 132 1b of thoria produced by the sol-gel process 4 , s and calcined in a hydrogen induction furnace for 2 hours at $2225^{\circ} \mathrm{F}$ was partially dissolved in 40 gallons of standard boiling dissolvent. The initial depth of thorla was $7.5 \mathrm{in.}(4 \mathrm{in}$. below top of 10-in.long circulator), and the final average "heel" depth (at a product concentration of $1 \mathrm{M} \mathrm{Th}^{4+}$ ) was $2.5 \mathrm{in.} \mathrm{As} \mathrm{shown} \mathrm{in} \mathrm{Figure} 11$, the dissolution rate increased from 3.7 to $44.8 \mathrm{lb} \mathrm{ThO}_{2} /\left(\mathrm{hr}-\mathrm{ft}^{2}\right)$ as the air flow was increased from 1 to $4 \mathrm{scfm}$. These values compare with an unagitated dissolution rate of $0.58 \mathrm{Ib} \mathrm{ThO}_{2} /\left(\mathrm{hr}-\mathrm{ft}^{2}\right)$. Two tests gave unexplainably high rates even though the material used for all tests came from the same thorla lot. Air flow to each of the 104 air lift circulators installed in the F-Area annular dissolver will be limited to 3 scfm to prevent exceeding the capacity of the off-gas exhaust system.

\section{Large-Scale Tests in Annular Dissolver Mockup}

Three dissolution tests were made in the rectangular mockup of the annular dissolver (modified to include 4 air lift circulators $1-1 / 2 \mathrm{in}$. above the $2-\mathrm{ft}^{2}$ bottom) to verify the data from the smallscale tests. For each test, a 500-1b charge of thoria (7.4 in. deep) was partially dissolved in 125 gallons of standard boiling dissolvent with 3 scfm air flow to each of the circulators. At a product concentration of $1 \mathrm{M} \mathrm{Th}^{4}$ and $8 \mathrm{M}$ HNO, the average "heel" depth was 3.3 in. A typical dissolution curve is shown in Figure 12. The results of these tests are summarized in Table II. 


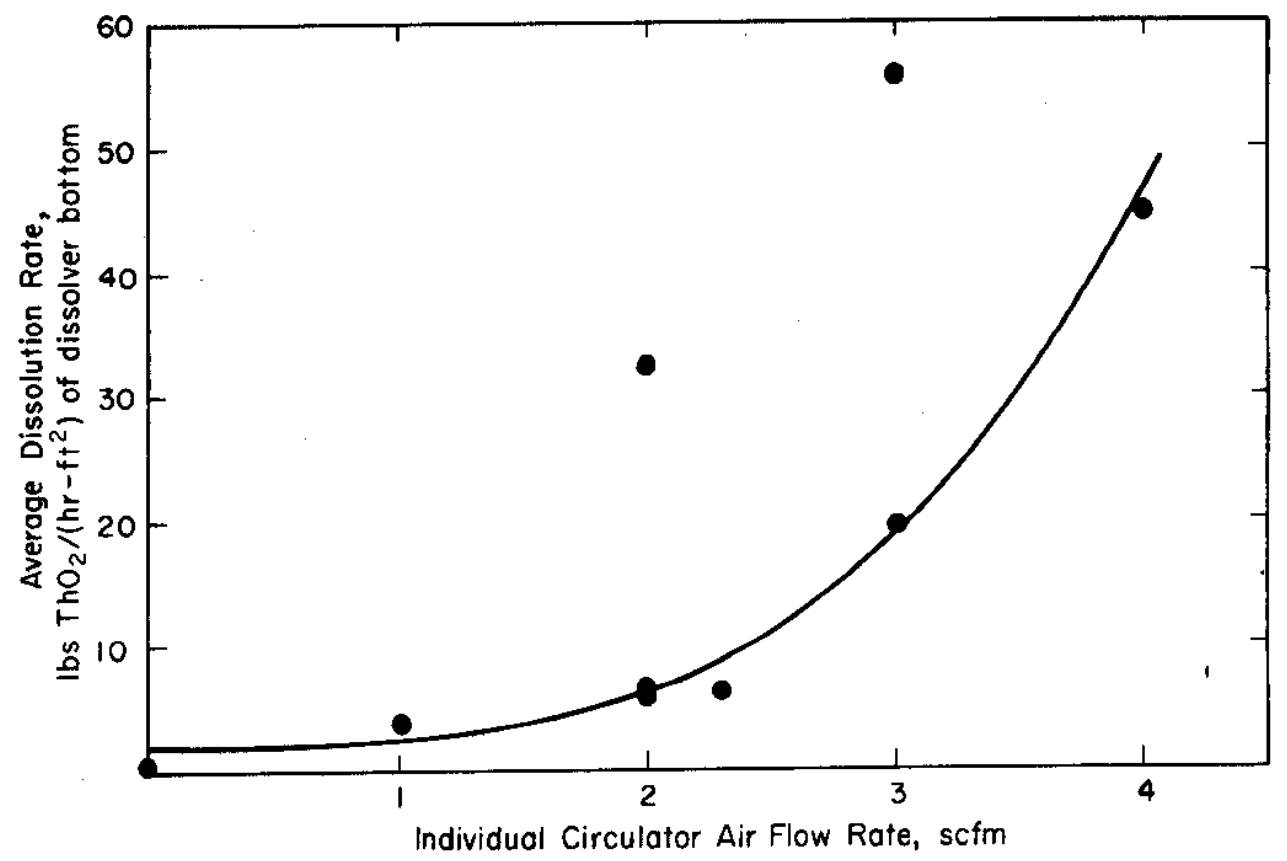

Figure 11. Effect of Circulator Air Flow on Thoria Dissolution

$\begin{aligned} \text { Dissolvent: } & 40 \mathrm{gal} \\ \text { Thoria: } & 132 \mathrm{lb}\end{aligned}$

Std. Lab. Diss. Test: 96.6 wt $\%$ in $6 \mathrm{hr}$

Diss. Bottom Area: $0.5 \mathrm{ft}^{2}$

No. of Circulators: 1

Table II. Large-Scale Dissolution Tests ${ }^{a}$ with Air Lift Circulators

Std. Lab. D1ss. Test, Time to Reach $1 \mathrm{M} \mathrm{Th}^{4}$, Avg. Diss. Rate,

Lot wt \% Diss. in $6 \mathrm{hr}$

hr from steam "on"

Ib $\mathrm{ThO}_{2} /\left(\mathrm{hr}^{\left.-\mathrm{ft}^{2}\right)}\right.$

$\begin{array}{llll}\text { G-71 } & 98.2 & 3.20 & 43.0 \\ \text { G-81 } & 99.9 & 1.66 & 82.9 \\ \text { G-105B } & 99.5 & 1.70 & 81.0\end{array}$

a. $500 \mathrm{1b} \mathrm{ThO}_{2}$ in 125 gallons of dissolvent with $3 \mathrm{scfm}$ per circulator (2 circulators $/ \mathrm{ft}^{2}$ of bottom). 


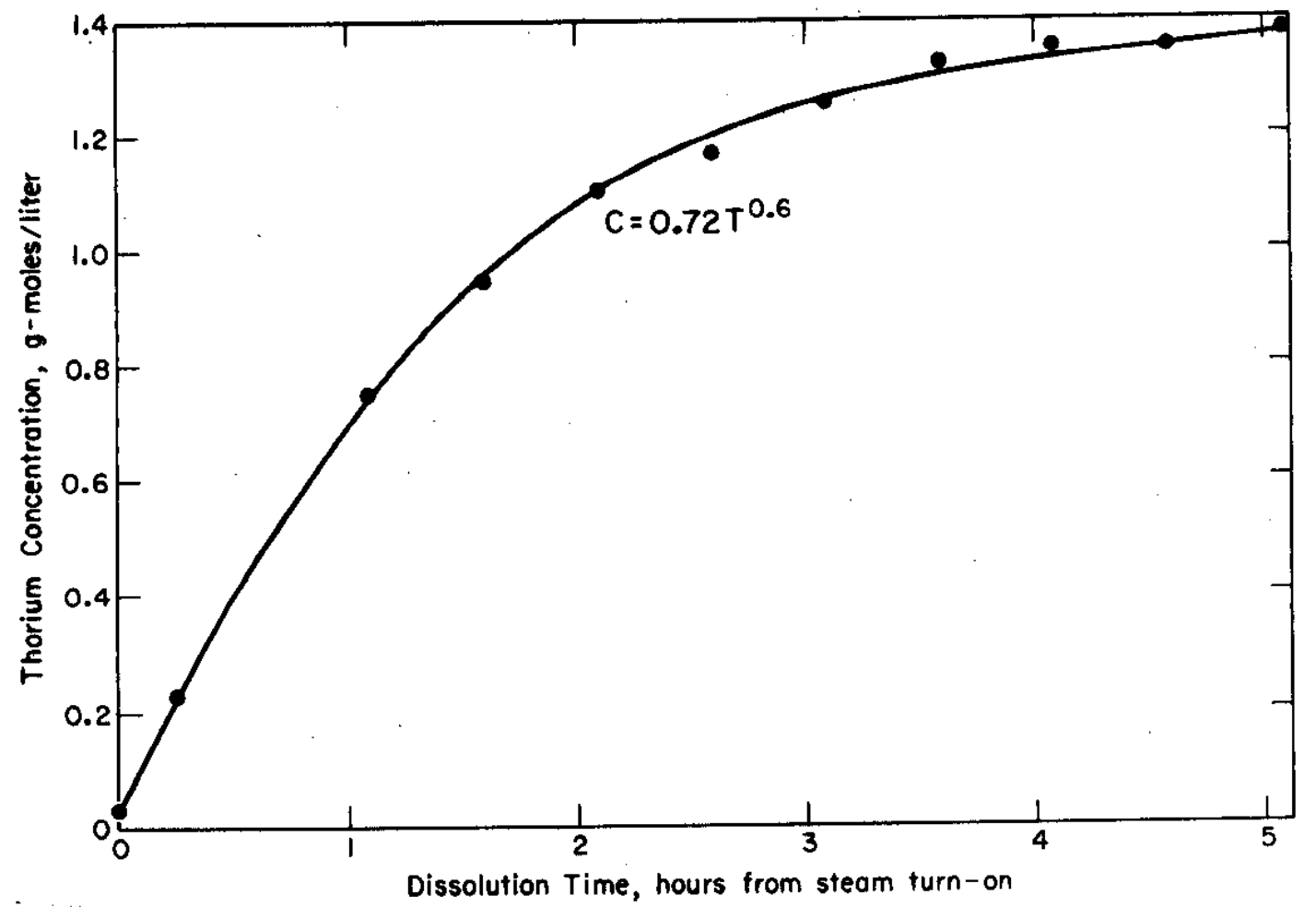

Figure 12. Dissolution of Thoria Agitated by Air Lift Circulators

\section{Dissolvent: 125 gal}

$$
\text { Thoria: } 500 \mathrm{ib}
$$

Std. Lab. Diss. Test: 99.9 wt \% in $6 \mathrm{hr}$

Diss. Bottom Area: $2 \mathrm{ft}^{2}$

No. of Circulators: 4

Air flow/Circulator: $3 \mathrm{scfm}$

The concentration of thorium (C) dissolved with agitation by alr lift circulators each operating at $3 \mathrm{scfm}$ can be expressed as a function of time $(T)$ by the formula:

$$
\mathrm{C}=\mathrm{AT}^{0.6}
$$

where the constant $A$ is dependent on the dissolving characteristics of the thoria and has a value between 0.25 and 0.75 . The varying dissolution rates (Table II) observed in these three thoria lots produced under similar conditions is relatively common. The varying rates are reflected in the results of the standard 6-hr laboratory test used for the dissolution specification $(20 \mathrm{~g} \mathrm{ThO}$ must be at least $95 \mathrm{wt} \%$ dissolved in $75 \mathrm{ml}$ of standard dissolvent with vigorous agitation within $6 \mathrm{hr}$ ). Based on the results of the standard laboratory dissolution test, the thoria used in the small scale tests (funnel dissolver) gave predictably lower dissolution rates $(96.6$ wt \% dissolved in $6 \mathrm{hr}$ ) than that dissolved under similar conditions in these large-scale tests. 
Because previous tests with air lift circulators were made only with thoria powder, aluminum-canned thorla was tested to demonstrate the entire reverse codfssolution cycle. The test was unsuccessful because the air lift circulators became plugged and resulted in a thoria dissolution rate of only $5 \mathrm{Ib} \mathrm{ThO}_{2} /\left(\mathrm{hr}-\mathrm{ft}^{2}\right)$. However, the solutions to several potential problems were revealed: 1) in order to avoid pluggage of the air supply, the circulators must be operated at all times when a thorla heel is present; however, during chemical removal of the aluminum cans in the last half of the delayed codissolution cycle, the air flow to the circulators may be reduced; 2) prior to removal of the spent dissolvent, dilution water must be added to prevent crystallization of $\mathrm{Al}\left(\mathrm{NO}_{3}\right)_{3}$ at ambient temperature (F1gure 1), which causes "cementation" of the densely packed thorfa hee1; and 3) suffictent solution must remain in the dissolver to maintain fluidization of the thoria by the operating circulators during removal of diluted spent dissolvent.

\section{Dissolution of Thoria Containing Magnesia}

Laboratory studies ${ }^{12}$ indicated that the incorporation of 1 wt \% magnesia ( $\mathrm{MgO}$ ) during sol-gel preparation would greatly enhance the thorla dissolution rate. The thoria dissolution is promoted because the magnesia dissolves readily in strong acid and causes the thoria to disintegrate into fine particles with large surface area. Three thoria lots containing magnesia were prepared by the Mallinckrodt Chemical Company and were calcined under varfous conditions in air in an induction furnace. Three "control" lots without magnesia were calcined under similar conditions for comparison. The characteristics of these six thoria lots are shown in Table III. Because samples from five of the thorla lots ware at least 99\% dissolved in the standard 6-hour laboratory test, a more definitive comparison was made by determining the time to reach $95 \%$ dissolution.

Table 111. Dissolution Characteristics of Thoria Containing Magnesium Oxide

\begin{tabular}{|c|c|c|c|c|c|c|}
\hline \multirow[b]{2}{*}{ Lot } & \multirow[b]{2}{*}{$\begin{array}{l}\text { Content, } \\
\% \\
\end{array}$} & \multirow[b]{2}{*}{$\frac{\text { Calcination }}{\text { Tempe } F}$} & \multirow[b]{2}{*}{$\frac{\text { Conditions }}{\mathrm{T} \text { ime, hr }}$} & \multirow[b]{2}{*}{$\begin{array}{l}\text { Particle Size } \\
\text { US Sieve Series }\end{array}$} & \multicolumn{2}{|c|}{ Std. Lab Diss. Test } \\
\hline & & & & & $\begin{array}{l}\text { Wt \% Dis8. } \\
\text { in } 6 \mathrm{hr}\end{array}$ & $\frac{\mathrm{Hr} \text { to D1s8. }}{95 \mathrm{wt} \%}$ \\
\hline 1339 & 0 & 2100 & 4 & $-40+100$ & 97.0 & $\begin{array}{l}6.0 \\
5.0\end{array}$ \\
\hline 1345 & 1 & 2100 & 4 & $\begin{array}{r}-6 \\
-40+100\end{array}$ & $<99$ & $\begin{array}{l}3.5 \\
2.75\end{array}$ \\
\hline 1341 & 0 & 2000 & 1.5 & $-40+100$ & 99 & $\begin{array}{l}2.5 \\
2.5\end{array}$ \\
\hline 1347 & 1 & 2000 & 1.5 & $\begin{array}{r}-6 \\
-40+100\end{array}$ & 99 & $\begin{array}{l}1.0 \\
1.25\end{array}$ \\
\hline 1351 & 0 & 1950 & 1.0 & $\begin{array}{r}-6 \\
-40+100\end{array}$ & $<99$ & $\begin{array}{l}0.08 \\
0.5\end{array}$ \\
\hline 1350 & 1 & 1950 & 1.0 & $\begin{array}{r}-6 \\
-40+100\end{array}$ & $<99$ & $\begin{array}{l}0.5 \\
0.75\end{array}$ \\
\hline
\end{tabular}


In each test with the annular dissolver mockup with the four air lift circulators operating at $3 \mathrm{scfm}$ each, a 500-1b charge of thoria was partially dissolved in 125 gallons of standard boiling dissolvent to a terminal concentration of $1 \mathrm{M} \mathrm{Th}^{4+}$. These tests (Figure 13) show that the thoria containing 1 wt \% magnesia dissolved more rapidly than the thoria without magnesia. The magnesiathorla mixture, which was calcined at the normal temperature of $2100^{\circ} \mathrm{F}$ for 4 hours, dissolved at a rate of $68.8 \mathrm{lb} /\left(\mathrm{hr}-\mathrm{ft}^{2}\right)$ compared to $17.2 \mathrm{lb} /\left(\mathrm{hr}-\mathrm{ft}^{2}\right)$ for the thorla without magnesia. The latter rate is just within the Iimits of the 6-hr laboratory dissolving specification. The dissolution rates increased with decreasing calcination temperatures (and length of calcination); this effect was much more pronounced with the untreated thoria. The one exception to these observations was the $1 \%$ magnesia-thoria mixture that was calcined for $1 \mathrm{hr}$ at $1950^{\circ} \mathrm{F}$ (Lot 1350). The reason for this discrepancy is not known, but the same irregularity occurred in the laboratory test (Table III) where the $-40+100$ mesh sample of this thoria lot took longer to reach $95 \%$ dissolution than the

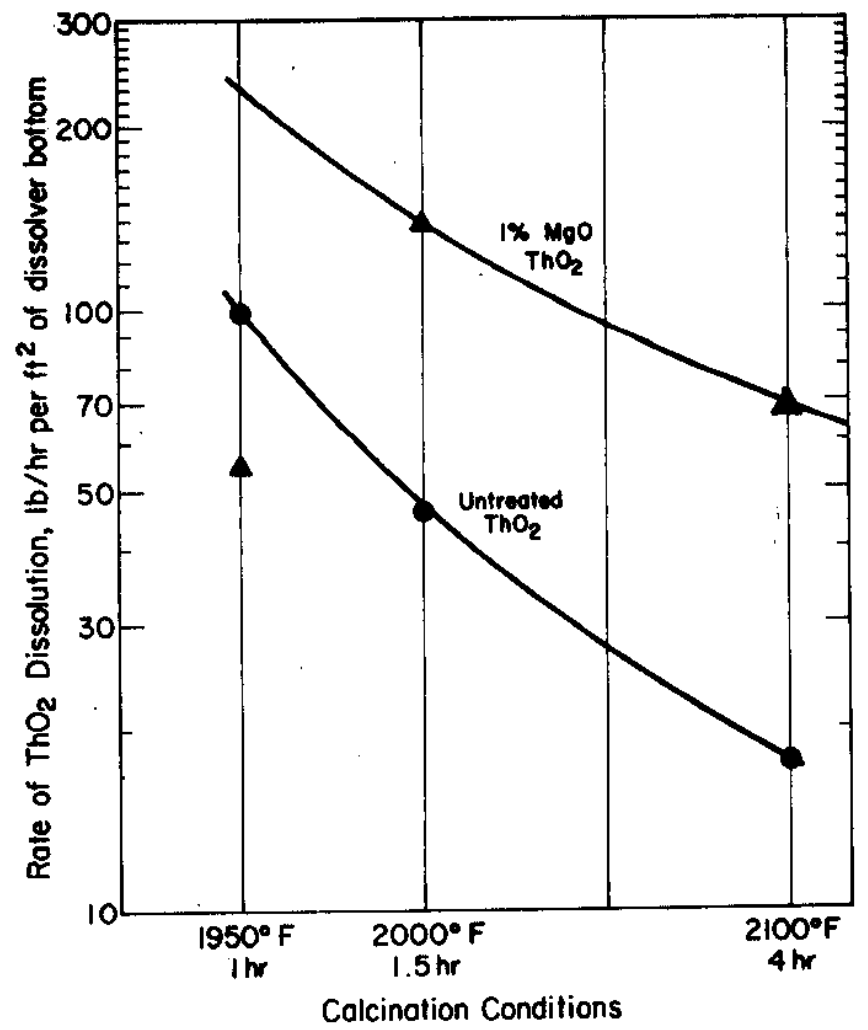

Figure 13. Agitated Dissolution of Thoria Containing Magnesia

Dissolvent: 125 gal

Thoria: $500 \mathrm{lb}$

Diss. Bottom Area: $2 \mathrm{ft}^{2}$

No. of Circulators: 4

Air flow/Circulator: $3 \mathrm{scfm}$ 
sample of the control thorla (Lot 1351).

At the end of each test with agitation, the spent dissolvent was removed, and the remaining thorla "heel" dissolved further in 80 gallons of fresh acid without agitation. The dissolution rates [less than $2 \mathrm{lb} /\left(\mathrm{hr}-\mathrm{ft}^{2}\right)$ ] indicate that incorporation of magnesia is not beneficial unless some means of agitation is employed (Table IV).

Table IV. Unagitated Dissolution of Thoria Containing Magnesia

\begin{tabular}{|c|c|c|c|c|}
\hline & Mg0 Content, & Calcination & Conditions & Avg. Dissolu \\
\hline Lot & wt $\%$ & Temp, ${ }^{\circ} \mathrm{F}$ & Time, hr & 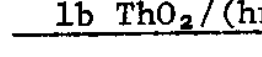 \\
\hline 1339 & 0 & 2100 & 4 & \\
\hline 1345 & 1 & 2100 & 4 & 1.1 \\
\hline $134 i$ & 0 & 2.000 & 1.5 & 1.15 \\
\hline 1347 & 1 & 2000 & 1.5 & 1.1 \\
\hline 1351 & 0 & 1950 & 1.0 & 1.8 \\
\hline 1350 & 1 & 1950 & 1.0 & \\
\hline
\end{tabular}

\section{Capacity of EM Annular Dissolver for F-Area}

A total of 104 slotted air lift circulators (2-in.-dia. $x$ 10-in. long) were installed $1-1 / 2$ in. above the $54 \mathrm{ft}^{2}$ bottom of the Extra Machinery (EM) annular dissolver for the F-Area separations plant. Separate manifolds in each annulus supplied air to the air lift circulators (Figure 14), and a protective grating was placed over the circulators in the inner annulus (FIgure 15) to prevent damage during fuel charging.

Operation of the air lift circulators at $3 \mathrm{scfm}$ each is expected to give dissolution rates much greater than $15 \mathrm{lb} \mathrm{ThO}_{2} /\left(\mathrm{hr}_{-} \mathrm{ft}^{2}\right)$. At this rate $\left(9.9 \mathrm{hr}\right.$ to dissolve 4.0 tons of $\left.\mathrm{ThO}_{2}\right)$, the predicted processing capacity would be 2.9 tons $\mathrm{ThO}_{2}$ /day using the same time for other processing steps as listed in Table I. At higher rates, the thoria dissolution time becomes relatively short, and the resulting dissolver capacity (Figure 16) is controlled by the amount of time used for other processing steps $(23.5 \mathrm{hr})$. Dissolution of thoria containing magnesia calcined at $2100^{\circ} \mathrm{F}$ [ (at a rate of $68.8 \mathrm{lb} /\left(\mathrm{hr}-\mathrm{ft}^{2}\right)$ ] would give a dissolver capactty of 3.7 tons $\mathrm{ThO}_{2} /$ day. The maximum capacity with instantaneous dissolution of the thoria is 4.1 tons $\mathrm{ThO}_{2} /$ day. 


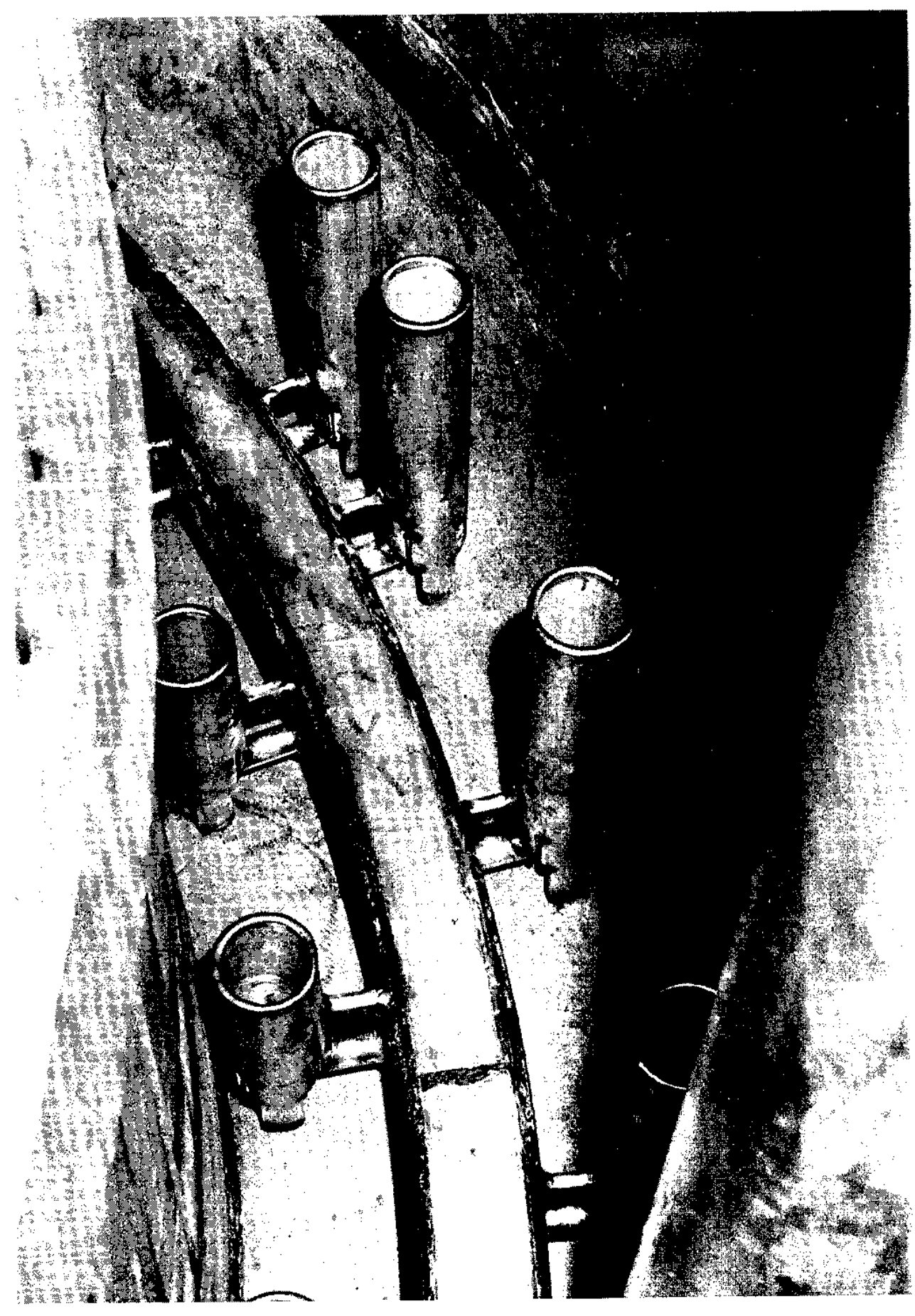

Figure 14. Air Lift Circulators in Plant Annular Dissolver 


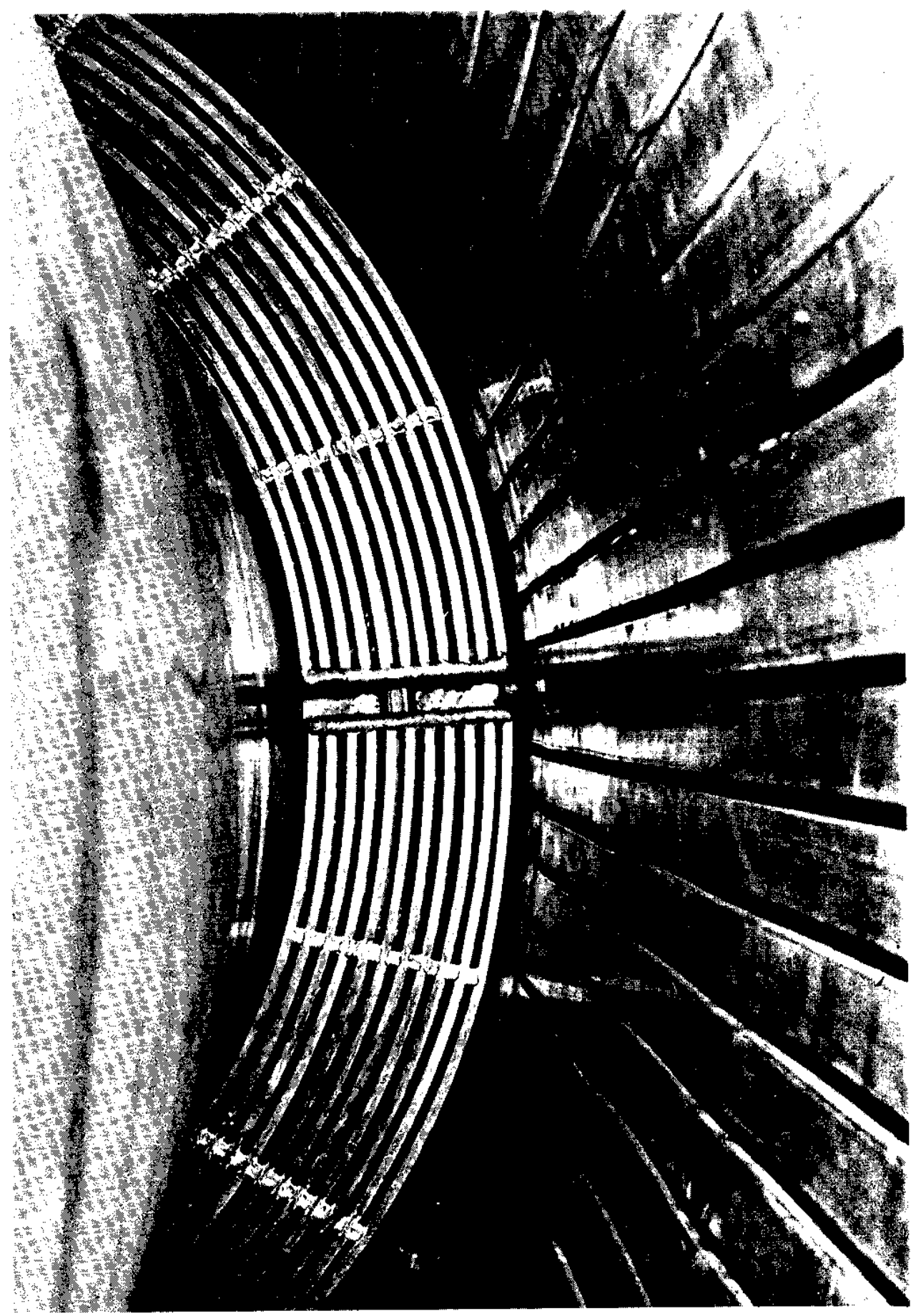

Figure 15. Protective Grating for Air Lift Circulators in Plant Annular Dissolver 


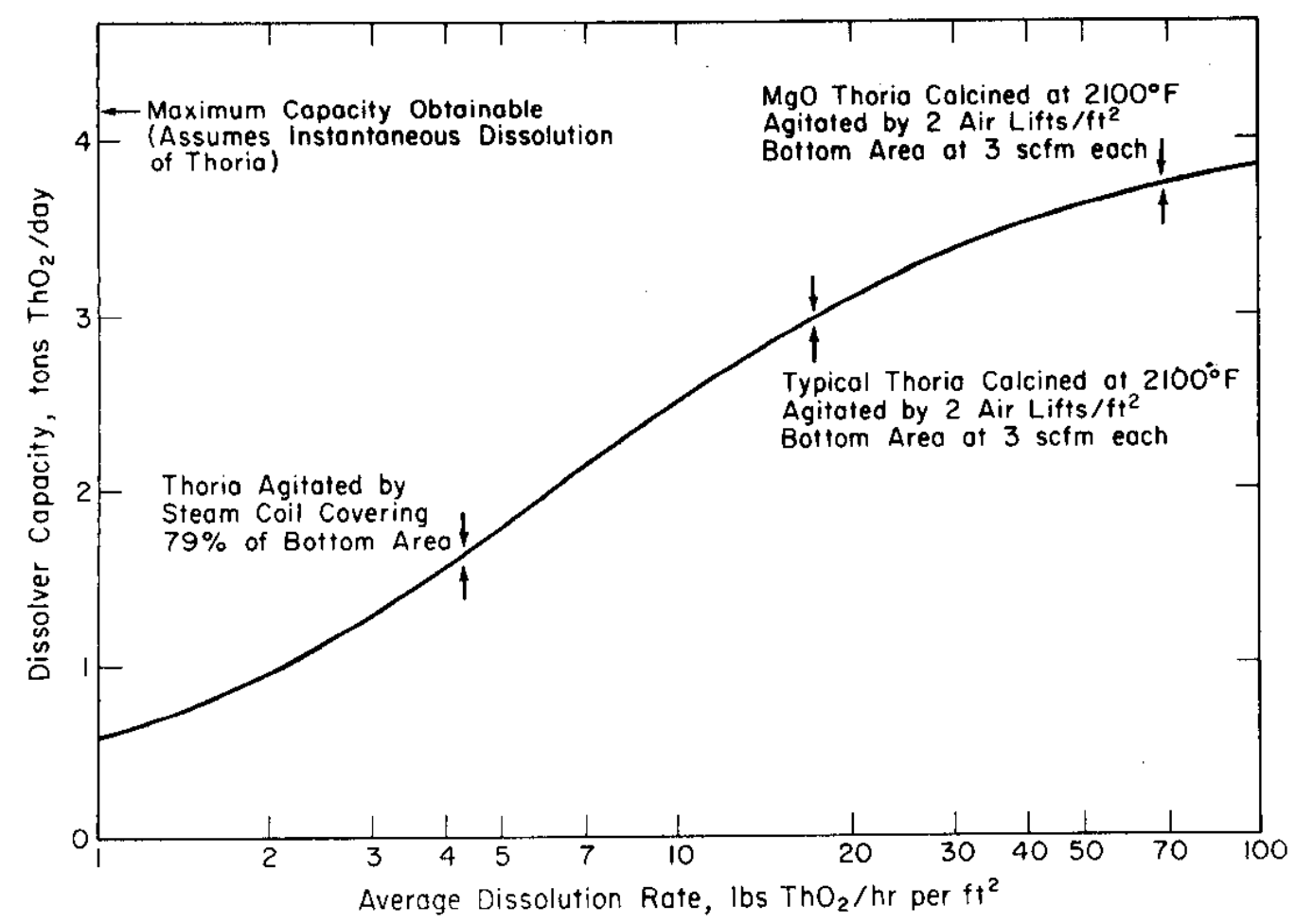

Figure 16. Capacity of Extra Machinery Annular Dissolver for F-Area

Entrainment of Thoria in Dissolver Solution

Pumping tests were made to determine how much thoria from the heel in the dissolver would be entrained in the solution removed from the dissolver vessel. With the end of the suction pipe $3 \mathrm{in}$. above the high side of the sloping (3/8-in./ft) bottom of the tank, 0.3 to $0.5 \%$ of the thoria was entrained. The same range of entrainment was observed with the suction pipe at either 5 or 9 in. from the bottom. The results are summarized in Table $V$.

Table V. Entrained Thoria in Dissolver Solution

Height of Suction

Pipe from

Bottom of Tank, in.

3

3

5
Flow Rate, gpm

11

30

30

30
Entrainment of Thorfa in Dissolver Solution, $\%$ of thorium dissolved

0.30

0.32

0.44

0.49 
Several attempts to filter the dissolver solution through two different-sized sintered stainless steel filters ( $98 \%$ removal at $12 \mu \mathrm{m}$ and at $2 \mu \mathrm{m}$ ) were unsuccessful; the entrained thoria blinded the filter rapidly. Centrifugation, however, decreased the entrained thoria to a value equivalent to only $0.006 \%$ of the total thorium.

\section{H-AREA POT DISSOLVER EXPERIENCE}

A 6-ft-dia. spiral steam coil was installed on the bottom of a 11-ft 4-in.-dia. pot dissolver in the H-Area Separations plant. The cross-sectional area of the steam coil (2-in. Schedule 80 pipe on 3-in. centers) covered only $22 \%$ of the dissolver's total bottom area (79\% of the 6-ft-dia crib section). During the first thoria processing campaign ( 88 tons of thorium), thoria dissolved at an average rate of $1.6 \mathrm{lb} /\left(\mathrm{hr}-\mathrm{ft}^{2}\right)$, for a dissolver capacity of 1.2 tons $\mathrm{ThO}_{2} /$ day. Although the average time required for dissolving 3.2 tons of thoria was 36 hours, this period was quite variable for apparently identical dissolving conditions. About $80 \%$ of the thoria dissolvings required 30 to 45 hours, but two dissolvings were completed in about 17 hours, and one required as much as 50 hours (a three-fold difference). The effectiveness of the steam coil during the first campaign was not clear, as several dissolvings made without steam pressure on the bottom coil gave dissolution rates similar to those obtained when the coil was in use. The effect of the coil may have been obscured by differences in the dissolving characteristics of individual lots of thoria, which have been observed to vary widely in the laboratory.

During the second thoria processing campaign (105 tons of thorium), an effect of the bottom steam coil on the dissolution rate was observed. In these dissolvings, the thoria dissolution rate without the bottom steam coil was 41 to $62 \%$ of that obtained when using the coil. However, it should be noted that this longer dissolution time decreased the dissolver capacity by only $\sim 10 \%$. The thoria dissolution rate without the bottom steam coil in operation was consistently less than the dissolutions made with steam to the bottom coil. The observed increase in dissolution rate obtained with the bottom steam coil operating is consistent with data obtained during experimental. tests, and contradicts results observed during the first thoria campaign. The effectiveness of the steam coil would be more apparent if the coil covered a larger fraction of the dissolver bottom.

Increased dissolving rates were also observed when 82 tons of thoria containing $1 \%$ magnesia was dissolved during the second thoria campaign. Dissolving rates were 20 to $30 \%$ faster for the four charges in which 40 to $75 \%$ of thoria targets contained $1 \%$ magnesia. Dissolving rates were not significantly faster in two charges in which magnesia-containing targets comprised $25 \%$ or less of the total charge. 
The results indicated that if all thoria contained $1 \%$ magnesia, the dissolving rate would increase about 40 to $50 \%$, and the overall dissolving time cycle would be reduced by about $10 \%$. A11 tests with magnesia additive were made with steam to the bottom coil in the dissolver; greater increases in dissolution rates would be expected if agitation were provided by air-lift circulators rather than steam coils.

\section{REFERENCES}

1. E. R. Russe11, M. L. Hyder, W. E. Prout, and C. B. Goodlett. "A Sol-Ge1 Thorium Oxide with Improved Dissolving Characteristics." Nuc. Sci. Eng. 30, 20-24 (1967).

2. M. L. Hyder, W. E. Prout, and E. R. Russe11. Dissolution of Thorizm Oxide. USAEC Report DP-1044, E. I. du Pont de Nemours and Co., Savannah River Laboratory, Aiken, S. C. (1966).

3. H. C. Rathvon, et a1. "Recovery of Uranium-233 from Irradiated Thoria." Proc. 2nd Intern. Thorium Fuel Cycle Symp., Gatlinburg, Tenn., May 3-6, 1966. USAEC Report CONF-660524, TID, Oak Ridge, Tenn. (1968) p. 765.

4. D. E. Ferguson, O. C. Deans, and D. A. Douglas. "The Sol-Gel Process for the Remote Preparation and Fabrication of Recycle Fuels." Proc. U. N. Intern. Conf.: Peaceful Uses Atomic Energy, 3rd, Geneva, 28/P1, 237 (1964).

5. W. J. Robertson, W. J. S. Smith, and T. H. Sublett. "Production of Thorium Oxide for Vibratory Compaction by a Modified So1-Ge1 Process," Proc. 2nd Interm. Thorium Fuel Cycle Symp., Gat1inburg, Tenn., May 3-6, 1966. USAEC Report CONF-660524, TID, Oak Ridge, Tenn. (1968) p. 735. 